\title{
Factors Predicting Creative Problem-Solving Competence in PISA 2012: Evidence from Six Countries
}

\author{
Serkan Arikan \\ Mugla Sitki Kocman University, Institute of Educational Sciences
}

\section{Abstract}

PISA measures the readiness level of 15-year-old students for the challenges they may encounter in their future lives, and evaluates their ability to reflect and to apply their knowledge to daily-life problems. PISA not only measures specific content domains such as mathematics, but also measures more general domains as creative problemsolving. Creative problem-solving is a new concept in PISA 2012, and identifying predictors of problem-solving for high, medium, and low achieving countries would be a novel and important topic. This study mainly investigated student and school characteristics that were effective in predicting problem-solving skills. Additionally, what would be the problem-solving performance difference among those countries if they had similar mathematics performance was identified. This study included students from Korea, the Netherlands, Norway, Ireland, Serbia and Turkey who had participated in PISA 2012. These six countries were considered to represent a fair spectrum for the participating countries in terms of creative problem-solving and mathematics performance. Multilevel regression analysis results showed that among student-level variables, openness for problem-solving, and experience with pure mathematics tasks predicted problem-solving performance positively in all countries. Socio-economic status predicted problem-solving performance positively in medium and low achieving countries. Surprisingly, experience with applied mathematics tasks predicted problem-solving performance negatively in all countries except Korea. School-level variables did not show a systematic pattern in predicting problem-solving performance. Among school-level variables, mathematics extracurricular activities, proportion of teachers with ISCED 5A, proportion of certified teachers and class size predicted problem-solving performance positively in some countries. ANCOVA 
results showed that the problem-solving difference among countries decreased when mathematics performance was controlled.

Key words: mathematics performance; multilevel analysis; PISA 2012; problemsolving competence.

\section{Introduction}

As the world becomes more integrated, achieving national goals and standards is not enough to compete with the developed countries. Comparing student performances, student and school characteristics internationally is an important way to evaluate success. The Programme for International Student Assessment (PISA) provides valuable data for mathematics, reading and science performance comparisons. PISA has recently provided detailed information about students' creative problem-solving competence. Problem-solving is a key component of success in a modern society. With the use of PISA data, it is possible to identify predictors of the problem-solving competence. By identifying significant factors that are associated with problem-solving, countries might investigate these factors. In this study, these factors were identified using PISA 2012 data from six countries (two high, two medium, and two low achieving countries as a result of problem-solving assessment). Additionally, detailed analyses were conducted to understand what the problem-solving performance differences among these countries would be if they had similar mathematics performance on PISA.

In today's modern society and workplaces, the necessity to solve non-routine or creative problems encountered almost every day is on the increase. As a result of this shift, the emphasis on the expected educational processes and outcomes is also changing. Now, the goals of educational systems are to prepare students for future world by equipping them with the ability to overcome complex and non-routine tasks. In order to measure these abilities specifically, creative problem-solving competence is measured in PISA as a separate assessment domain. The problem-solving competence is defined in PISA 2012 assessment (OECD, 2013a, p. 122) as:

an individual's capacity to engage in cognitive processing to understand and resolve problem situations where a method of solution is not immediately obvious. It includes the willingness to engage with such situations in order to achieve one's potential as a constructive and reflective citizen.

With providing a separate problem-solving domain, PISA aimed to measure how well 15-year-olds were educated to cope with real life problem situations they have never met before. The creative problem-solving assessment of PISA gives emphasis to cognitive processes activated when solving problems, rather than solving problems related to specific school subjects. Items in problem-solving do not require any content expertise (OECD, 2014a). Subject specific problem-solving tasks are also measured in other sections of PISA assessment, such as in the mathematics domain (OECD, 
2013a). PISA reported related validity analyses which showed that problem-solving constituted a separate domain from mathematics and other domains (OECD, 2014a).

The PISA problem-solving domain was administered for the first time in 2003 in a paper and pencil format. In 2012, problem-solving administration through computerbased assessment was used in a more challenging and interactive format. Therefore, the latest format was new in measuring problem-solving competence of 15 -year-olds. It is important to note that some countries performed better or worse than expected on problem-solving compared to their mathematics performance. For example, among high, medium and low achieving countries, Korea, Norway, and Serbia, respectively, got higher scores than expected on problem-solving. However, among high, medium and low achieving countries, the Netherlands, Ireland, and Turkey, respectively, achieved lower scores on problem-solving than expected (OECD, 2014a). Therefore, identifying predictors of problem-solving performance is expected to give clues about incentives behind these performance differences. Investigating correlates of creative problemsolving measured in PISA 2012 is a novel topic, which is expected to contribute to the educational literature.

\section{Factors Predicting the Problem-Solving Performance Differences}

Walberg $(1981,1984,2004)$ proposed a theoretical framework (Model of Educational Productivity) which is widely used in achievement studies that investigated predictors of achievement. In the model, three groups of factors were defined to be related to student achievement: student aptitude variables, environmental variables, and instructional variables. Walberg's model and hierarchical structure of PISA (studentlevel and school-level) guided this study in organizing and selecting predictors of problem-solving performances. Student aptitude variables are related to student motivation and self-concept. Environmental variables involve home, classroom and peers related variables. This factor is related to the social-psychological climate of home, classroom, and peer group. Instructional variables include quantity, time and quality of instruction. This factor indicates instructional aspects that affect learning. Student-level variables that could be predictors of problem-solving performances in PISA are economic, social and cultural status, perseverance and openness for problem-solving, experience with pure and applied mathematics tasks at school. Among these variables, perseverance and openness for problem-solving were selected to represent student aptitude variables; economic, social and cultural status were selected as environmental variables; experience with pure and applied mathematics tasks at school were categorized under instructional variables of Walberg's Model. Perseverance and openness for problem solving are motivational and affective factors about students' willingness to engage in problem-solving. Perseverance and openness for problem solving were found to be associated with the problem-solving competence (Funke, 2010; Kogar, 2015; Mayer, 1998; Perkins \& Shiel, 2014; Scherer \& Gustafsson, 2015). Economic, social and cultural status (ESCS) is an occupational, educational, 
wealth, and cultural indicator of a family. Many studies showed that there was a positive relationship between ESCS and problem-solving or mathematics performance (Akyüz \& Pala, 2010; Alacacı \& Erbaş, 2010; Bae \& Wickrama, 2015; Perkins \& Shiel, 2014). Experience with pure and applied mathematics tasks at school are opportunityto-learn indicators that showed a significant relationship with performance in PISA (Schmidt, Zoido, \& Cogan, 2014).

School-level variables that could be predictors of problem-solving performance in PISA are class size, proportion of certified teachers, proportion of teachers with ISCED 5A (International Standard Classification of Education), quality of school educational resources, extracurricular creative activities at school, mathematics extracurricular activities at school. Class size, proportion of certified teachers, proportion of teachers with ISCED 5A and quality of school educational resources were selected to represent environmental variables of Walberg's Model. Extracurricular creative activities at school and mathematics extracurricular activities at school were categorized under instructional variables of Walberg's Model. Class size was considered to affect student performance (OECD, 2013b). However, the results were mixed based on the relationship between class size and student performance (Breton, 2014; Hattie, 2005). Proportion of certified teachers and proportion of teachers with ISCED 5A are indicators of teacher quality in a school. ISCED 5A is one of the classifications of all study programs which is equivalent to university degree (OECD, 1999). Better quality of school educational resources was shown to be related to student performance in some countries (Areepattamannil, 2014). Some scholars found that the effectiveness of quality of school educational resources differed across countries (Aztekin \& Yilmaz, 2014). Extracurricular creative activities at school and mathematics extracurricular activities at school are indicators of activities conducted in a school. Participation in extracurricular activities had resulted in positive and negative outcomes (Guèvremont, Findlay, \& Kohen, 2014). Fiore (2015) reported that there was a weak relationship between mathematics extracurricular activities and math scores.

\section{Present Study}

It is expected from schools not only to develop regular curriculum based objectives but also to develop students' problem-solving abilities. Students should be equipped with better problem-solving skills. In order to achieve this, educators should be informed about student and school characteristics that are effective in predicting problem-solving skills. Investigating significant predictors of problem-solving in high, medium and low achieving countries is expected to give some clues. OECD reported that some countries performed lower than expected on problem-solving compared to their mathematics scores (OECD, 2014a). Therefore, it was also necessary to investigate the expected problem-solving performance of these countries. This study contributes to the literature by identifying correlates of problem-solving performance. The research questions of this study are: 
1. Which student- and school-level factors predict students' problem-solving performances in high, medium and low achieving countries in PISA 2012?

2. What would be the problem-solving performance differences among these countries, if students had similar mathematics performance?

The hypotheses of the study are:

1. We could predict problem-solving performances of students in high, medium and low achieving countries using student- and school-level factors.

2. There would be problem-solving performance differences among these countries, if students had similar mathematics performance.

\section{Methods}

\section{Participants}

The data of the study were obtained from the PISA 2012 database. In PISA, the target population are 15-year-old students of participating countries. This study used all students who had participated in PISA 2012 from Korea, the Netherlands, Norway, Ireland, Serbia and Turkey. These six countries were selected as Korea and the Netherlands had mean scores higher than average, Norway and Ireland had mean scores around the average, and Serbia and Turkey got mean scores lower than average on problem-solving assessment. Additionally, Korea, Norway and Serbia got higher problem problem-solving scores than expected compared to mathematics score ranking, and the Netherlands, Ireland, and Turkey got scores lower than expected. Therefore, these six countries were considered to represent a fair spectrum for the participating countries (OECD, 2014a).

Table 1

Gender and grade level information of participating students

\begin{tabular}{|c|c|c|c|c|c|c|c|c|c|}
\hline \multirow[b]{2}{*}{ Country } & \multirow[b]{2}{*}{$\mathrm{N}$} & \multicolumn{2}{|c|}{ Gender } & \multicolumn{6}{|c|}{ Grade } \\
\hline & & Female (\%) & Male (\%) & $\begin{array}{c}7 \\
(\%)\end{array}$ & $\begin{array}{c}8 \\
(\%)\end{array}$ & $\begin{array}{c}9 \\
(\%)\end{array}$ & $\begin{array}{c}10 \\
(\%)\end{array}$ & $\begin{array}{c}11 \\
(\%)\end{array}$ & $\begin{array}{c}12 \\
(\%)\end{array}$ \\
\hline Korea & 5033 & 46.5 & 53.5 & - & - & 5.9 & 93.9 & .2 & - \\
\hline Netherlands & 4460 & 48.1 & 51.9 & - & 3.5 & 49.1 & 46.9 & .5 & - \\
\hline Norway & 4686 & 48.9 & 51.1 & - & - & .4 & 99.5 & .0 & - \\
\hline Ireland & 5016 & 50.7 & 49.3 & .1 & 1.8 & 62.3 & 23.5 & 12.3 & - \\
\hline Serbia & 4684 & 50.6 & 49.4 & .0 & .5 & 97.7 & 1.7 & - & - \\
\hline Turkey & 4848 & 48.9 & 51.1 & .4 & 2.0 & 27.2 & 66.0 & 4.0 & .3 \\
\hline
\end{tabular}

In PISA 2012, the two-stage stratified sample design was used. In the first stage, the schools were selected with the probability proportional to the number of eligible 15 -year-old students in a school. At least 150 schools were selected from each country. In the second stage, students in selected schools were sampled with equal probability. The number of students sampled from each school was nearly 35 (OECD, 2013a). In PISA 2012, the data of 5033 students from Korea, 4460 students from the Netherlands, 
4686 students from Norway, 5016 students from Ireland, 4684 students from Serbia, and 4848 students from Turkey were available. The number of female and male students was almost the same for all countries. Students who attended PISA 2012 were generally $9^{\text {th }}$ or $10^{\text {th }}$ graders (see Table 1 ).

\section{Measures}

PISA 2012 gathered data about students' problem-solving performance via problem-solving test; about student characteristics via student questionnaire; and about school characteristics via school questionnaire (administered to principals). PISA 2012 problem-solving assessment was administered on a computer. Items of problem-solving assessment were related to out of school situations students might encounter in their daily life such as technology devices (remote control, clock, etc.) or unfamiliar spaces (traffic, getting lost, etc.). These items were not related to content and curriculum based information. Texts were short and easy to read, and in arithmetic operations, a calculator was provided on the screen. The problem-solving items were prepared considering three distinct aspects: nature of the problem situation which was related to whether all the information needed to solve the problem was given or not; problem-solving process which was related to main cognitive processes involved in the particular task, such as exploring and understanding, representing and formulating, planning and executing, monitoring and reflecting; problem content which was related to whether the everyday scenario involved a technological device or not and whether the everyday scenario involved a personal or social environment. A total of 42 items within 16 units grouped into 4 clusters were administered to students to measure their problem-solving performance (OECD, 2014a). Released problem-solving items were given in the following website: http://www.oecd.org/ pisa/pisaproducts/pisa2012problemsolvingquestions.htm. PISA provides five plausible scores for each student representing students' problem-solving performance using multiple imputation. These scores were estimated using the Item Response Theory (IRT). Ability scores obtained in IRT analysis were transformed to plausible scores by setting OECD mean score of 500 and standard deviation of 100 . Overall reliability of problem-solving items was reported as 0.88 (OECD, 2014b).

In the study, economic, social and cultural status (ESCS), perseverance and openness for problem-solving, and experience with pure and applied mathematics tasks at school were used for student-level variables. The index of ESCS was reported by PISA as a combination of the highest occupational status of parents, the highest educational level of parents, family wealth, cultural possessions, and home educational resources (OECD, 2014b). The index of perseverance was estimated by PISA based on student agreement on the following statements: "when confronted with a problem, I give up easily; I put off difficult problems; I remain interested in the tasks that I start; I continue working on tasks until everything is perfect; when confronted with a problem, I do more than what is expected of me". The index of openness for problem- 
solving was reported by PISA based on student agreement on the following statements: "I can handle a lot of information; I am quick to understand things; I seek explanations of things; I can easily link facts together; I like to solve complex problems" (OECD, 2014a). In order to measure experience with applied and pure mathematics tasks at school, frequency of student-perceived experiences using items such as "working out from a train timetable how long it would take to get from one place to another" and "solving an equation like $6 \mathrm{x}^{2}+5=29$ " were used, respectively (OECD, 2014b). These scale indices were constructed through scaling of items using IRT. ESCS median reliability was 0.65 ; perseverance median reliability was 0.80 ; openness for problemsolving median reliability was 0.82 ; experience with pure mathematical task median reliability was 0.92 ; experience with applied mathematical task median reliability was 0.77 (OECD, 2014b).

School-level variables of the study were class size, proportion of certified teachers, proportion of teachers with ISCED 5A, quality of school educational resources, extracurricular creative activities at school, and mathematics extracurricular activities at school. Class size was reported by PISA to indicate the number of students in a classroom. Proportion of certified teachers and proportion of teachers with ISCED $5 \mathrm{~A}$ were reported by PISA to indicate quality of teachers in a school. Index of quality of school educational resources was created by PISA using factors such as shortage or inadequacy of science laboratory equipment; shortage or inadequacy of instructional materials; shortage or inadequacy of computers for instruction; lack or inadequacy of internet connectivity; shortage or inadequacy of computer software for instruction; and shortage or inadequacy of library materials. A high score on the quality of school educational resources indicated that a school had better educational resources. Index of extracurricular creative activities at school was derived by PISA based on a number of activities at school such as band, orchestra or choir; school play or school musical, and art club or art activities. Index of mathematics extracurricular activities at school was reported by PISA based on activities at school such as mathematics club; mathematics competition; club with a focus on computers I Information Communication Technology; and additional mathematics lessons (OECD, 2013b). The scale index of Quality of school educational resources was constructed through scaling of items using IRT. Median reliability of this index was 0.81 (OECD, 2014b). The other school-level variables were calculated based on the number of related indicators.

\section{Data Analysis}

In order to answer the first research question, using data from six countries (Korea, the Netherlands, Norway, Ireland, Serbia, and Turkey), student and school-level predictors of problem-solving performance were identified. As the PISA data had a hierarchical structure in which students were nested in schools, a multilevel regression analysis (random intercepts model) was conducted for each country separately. 
Significant factors were reported and explained, the problem-solving variances within and between schools were calculated. In the analysis, student-level variables (ESCS, perseverance and openness for problem-solving, experience with pure and applied mathematics tasks at school), and school-level variables (class size, proportion of certified teachers, proportion of teachers with ISCED 5A, quality of school educational resources, extracurricular creative activities at school, mathematics extracurricular activities at school) were independent variables, whereas five plausible problemsolving performance scores of students were dependent variables. The multilevel analyses were conducted by MPLUS 7.4. The MPLUS program was used as it is capable of conducting multilevel analysis by taking into account five plausible problem-solving scores of students reported in PISA (Muthen \& Muthen, 2015).

In order to answer the second research question, Analysis of Covariance (ANCOVA) was conducted as mathematics performance was used as a covariate, problem-solving performance was used as a dependent variable and countries were used as the grouping variable. Therefore, controlling mathematics performance, what would be the expected problem-solving performance of these countries were estimated. ANCOVA results were used to identify expected problem-solving performance difference among these countries if they had similar mathematics performance. ANCOVA was conducted using the SPSS 20.0 program.

\section{Results}

\section{Descriptive Statistics}

In this section, means of independent and dependent variables were presented (see Table 2). The values were estimated using IDB Analyzer program to take care of sampling weights based on the PISA sampling procedure (International Association for the Evaluation of Educational Achievement, 2013). For ESCS, Norway and Turkey had the highest and the lowest mean, respectively. For perseverance and class size, Turkey and Norway had the highest and the lowest mean, respectively. For openness to problem-solving, Serbia had the highest and Korea had the lowest mean. For experience with applied mathematics tasks, Korea and Serbia had the highest and the lowest mean, respectively. For experience with pure mathematics tasks, Korea had the highest and Turkey had the lowest mean. For proportion of certified teachers, Korea and Ireland had the highest and the Netherlands had the lowest mean. For proportion of teachers with ISCED 5A, Korea, Norway and Ireland had the highest and Serbia had the lowest mean. For quality of school educational resources, the Netherlands and Serbia had the highest and the lowest mean, respectively. For extracurricular creative activities, and mathematics extracurricular activities, Korea had the highest and Norway had the lowest mean.

For problem-solving and mathematics performance, Korea had the highest and Turkey had the lowest mean. Generally, problem-solving scores were higher than mathematics scores except for the Netherlands. When Norway and Ireland were 
compared, although Ireland had higher score on mathematics, Irish students showed lower performance on problem-solving. Similarly, although Serbia and Turkey had very close mathematics performance, Serbia got around 20 points higher than Turkey on problem-solving.

Among these values, it is worthwhile to note that, Korean students had higher experience with mathematics tasks and they had many mathematics extracurricular activities. Although Korean students got very high problem-solving scores, students reported that they were less open to problem-solving. Additionally, classrooms in Turkey and Korea were more crowded than other countries. Low achieving countries, Serbia and Turkey, had very limited school educational resources compared to other countries.

Table 2

Mean of student- and school-level variables

\begin{tabular}{|c|c|c|c|c|c|c|}
\hline & Korea & Netherlands & Norway & Ireland & Serbia & Turkey \\
\hline \multicolumn{7}{|l|}{ Level-1 } \\
\hline $\begin{array}{l}\text { Economic, social and cultural } \\
\text { status }\end{array}$ & .01 & .23 & .46 & .13 & -.30 & -1.46 \\
\hline Perseverance & -.09 & -.13 & -.34 & .15 & .20 & .45 \\
\hline $\begin{array}{l}\text { Openness for problem- } \\
\text { solving }\end{array}$ & -.37 & -.08 & .18 & -.02 & .46 & .21 \\
\hline $\begin{array}{l}\text { Experience with applied } \\
\text { math tasks }\end{array}$ & .40 & .22 & .18 & .14 & -.24 & -.17 \\
\hline $\begin{array}{l}\text { Experience with pure math } \\
\text { tasks }\end{array}$ & .43 & -.01 & .00 & .14 & -.08 & -.10 \\
\hline \multicolumn{7}{|l|}{ Level-2 } \\
\hline Class size & 33.60 & 25.18 & 24.68 & 24.90 & 28.04 & 43.96 \\
\hline $\begin{array}{l}\text { Proportion of certified } \\
\text { teachers }\end{array}$ & 1.00 & .80 & .89 & 1.00 & .91 & .92 \\
\hline $\begin{array}{l}\text { Proportion of teachers with } \\
\text { ISCED } 5 A\end{array}$ & 1.00 & .32 & 1.00 & 1.00 & .07 & .93 \\
\hline $\begin{array}{l}\text { Quality of school } \\
\text { educational resources }\end{array}$ & .06 & .19 & -.19 & .11 & -.56 & -.40 \\
\hline $\begin{array}{l}\text { Extracurricular creative } \\
\text { activities }\end{array}$ & 2.06 & 1.85 & .68 & 1.56 & 2.00 & 1.71 \\
\hline $\begin{array}{l}\text { Mathematics extracurricular } \\
\text { activities }\end{array}$ & 4.08 & 1.24 & .99 & 1.81 & 2.78 & 1.76 \\
\hline Problem-solving performance & 561.10 & 510.71 & 503.34 & 498.34 & 473.44 & 454.49 \\
\hline Mathematics performance & 553.77 & 522.97 & 489.37 & 501.50 & 448.86 & 447.98 \\
\hline
\end{tabular}

\section{Factors Predicting Problem-Solving Performance}

Assumptions of multilevel regression statistics were checked. Normality, linearity and homogeneity of error variances assumptions were investigated. Investigating residuals gives information about assumptions of normality, linearity and heteroscedasticity (Hox, 2010). In order to test these assumptions, the standardized residuals against the 
predicted values plot were investigated (Tabachnick \& Fidell, 2013). For all countries, it was observed that these assumptions were not violated.

In order to answer the first research question and hypothesis, multilevel regression results were reported for each country (see Table 3). The results indicate that it was possible to predict problem-solving performances of students in high, medium and low achieving countries using student- and school-level factors. Student-level variables explained variance in problem-solving performance differently for each country, from $10 \%$ (in Serbia) to $22 \%$ (in Korea and in Ireland) (the median is 15.5\%). The difference of explained variance within school among countries implied that the multilevel model of the study was more effective for Korea, Ireland and Norway compared to other countries. This means that for the Netherlands, Serbia and Turkey, there were other student-level variables that might explain differences among students, such as anxiety. Openness for problem-solving and experience with pure mathematics tasks were two variables that predicted problem-solving performance positively in all countries. Therefore, students who were more open to problem-solving and who had more experience with pure mathematical tasks got higher scores on problemsolving. Surprisingly, experience with applied mathematics tasks predicted problemsolving performance negatively in all countries except Korea, the highest achieving country. ESCS predicted problem-solving performance positively in medium and low achieving countries. This means that a student with better resources at home got higher scores on problem-solving. However, in Korea and the Netherlands, the highest achieving countries, no association was found between ESCS and problem-solving. Therefore, it is concluded that for high achieving countries, ESCS did not have a role in this prediction. Among the student-level variables, perseverance predicted problemsolving positively only for Norway and Ireland.

School-level variables explained variance in problem-solving performance varying from $3 \%$ (in Norway) to $39 \%$ (in the Netherlands) (the median is $24 \%$ ). The explained variance between schools in the multilevel model of the study was almost equally effective in predicting problem-solving, except for Norway, where the explained variance was very low. Therefore, it was concluded that there were other schoollevel variables that might explain differences among schools. School-level variables did not show a systematic pattern in predicting problem-solving performance like student-level variables. Mathematics extracurricular activities available in schools were found to have a positive relationship with problem-solving performance in Korea and Turkey. Schools with more teachers with ISCED 5A and crowded classrooms showed higher performance in the Netherlands and Ireland. Schools with more certified teachers were more successful in problem-solving in Serbia. Quality of school educational resources predicted problem-solving performance significantly only in Korea and Turkey, negatively and positively, respectively. Only extracurricular creative activities did not show an association with problem-solving in any country. Therefore, it could be deduced partially that having less crowded classrooms with 
more educated teachers who conduct more mathematics extracurricular activities might lead to higher problem-solving scores.

Table 3

Standardized regression coefficients for problem-solving performance prediction

\begin{tabular}{|c|c|c|c|c|c|c|}
\hline & Korea & Netherlands & Norway & Ireland & Serbia & Turkey \\
\hline \multicolumn{7}{|l|}{ Level-1 } \\
\hline $\begin{array}{l}\text { Economic, social and } \\
\text { cultural status }\end{array}$ & .023 & .083 & $.136^{* * *}$ & $.165^{* * *}$ & $.199 * * *$ & $.220^{* * *}$ \\
\hline Perseverance & -.019 & -.050 & $.098^{* *}$ & $.088^{* *}$ & .007 & .068 \\
\hline $\begin{array}{l}\text { Openness for } \\
\text { problem-solving }\end{array}$ & $.287^{* * *}$ & $.178^{* * *}$ & $.204^{* * *}$ & $.252^{* * *}$ & $.170^{* * *}$ & $.113^{* *}$ \\
\hline $\begin{array}{l}\text { Experience with } \\
\text { applied math tasks }\end{array}$ & -.029 & $-.177^{* * *}$ & $-.126^{* * *}$ & $-.097^{* *}$ & $-.116^{* *}$ & $-.110^{* *}$ \\
\hline $\begin{array}{l}\text { Experience with pure } \\
\text { math tasks }\end{array}$ & $.312^{* * *}$ & $.274^{* * *}$ & $.270^{* * *}$ & $.243^{* * *}$ & $.125^{* *}$ & $.146^{* * *}$ \\
\hline \multicolumn{7}{|l|}{ Level-2 } \\
\hline Class size & .008 & $.247^{*}$ & .053 & $.395^{* * *}$ & .163 & -.104 \\
\hline $\begin{array}{l}\text { Proportion of } \\
\text { certified teachers }\end{array}$ & -.234 & .051 & .108 & -.044 & $.386^{* *}$ & -.016 \\
\hline $\begin{array}{l}\text { Proportion of } \\
\text { teachers with ISCED } \\
5 \mathrm{~A}\end{array}$ & .197 & $.403^{* * *}$ & NA & $.214^{* * *}$ & .277 & -.108 \\
\hline $\begin{array}{l}\text { Quality of school } \\
\text { educational } \\
\text { resources }\end{array}$ & $-.186^{*}$ & -.060 & .030 & .153 & -.037 & $.181^{*}$ \\
\hline $\begin{array}{l}\text { Extracurricular } \\
\text { creative activities }\end{array}$ & .069 & -.036 & .073 & -.055 & .152 & .126 \\
\hline $\begin{array}{l}\text { Mathematics } \\
\text { extracurricular } \\
\text { activities }\end{array}$ & $.412^{* * *}$ & .124 & .028 & .070 & .160 & $.333^{* * * *}$ \\
\hline $\begin{array}{l}\text { Explained variance } \\
\text { within schools }\end{array}$ & $22 \%$ & $11 \%$ & $19 \%$ & $22 \%$ & $10 \%$ & $12 \%$ \\
\hline $\begin{array}{l}\text { Explained variance } \\
\text { between schools }\end{array}$ & $24 \%$ & $39 \%$ & $03 \%$ & $24 \%$ & $17 \%$ & $24 \%$ \\
\hline
\end{tabular}

Note: NA means Not Applicable (there was zero variation). ${ }^{*} p<.05 .{ }^{* *} p<.01 .{ }^{* * *} p<.001$.

\section{Comparison of Expected Problem-Solving Performance when Controlling Mathematics Performance}

In order to answer the second research question and hypothesis, the expected problem-solving performance difference among these countries if they had similar mathematics performance was investigated. Problem-solving performance without and with controlling (adjusted mean) mathematics performance is reported in Table 4. Firstly, without controlling mathematics performance, a one-way between subjects ANOVA was conducted to compare problem-solving performance differences. There was a statistically significant difference among these countries $(F(5,28721)=756.78$; $\left.p=.000 ; \eta^{2}=.12\right)$. Then, with controlling mathematics performance, ANCOVA was 
conducted to compare expected problem-solving performance differences. There was still a significant difference among these countries $(F(5,28720)=198.04 ; p=.000$; $\left.\eta^{2}=.01\right)$. Eta-squared value before controlling mathematics performance indicated medium level differences among countries. However, when mathematics performance was controlled, eta-squared value indicated small level differences among countries (Cohen, 1988). Eta-squared value decreased dramatically, which indicated that there would be smaller score differences on problem-solving among these countries if these countries had similar mathematics performance. Therefore, the answer to the second hypothesis was that there was smaller problem-solving performance difference among these countries, if students had similar mathematics performance.

Post-hoc analyses, using the Bonferroni procedure, were conducted to evaluate pairwise differences among adjusted problem-solving mean scores. The results showed that although adjusted problem-solving score of Korea would be lower, Korea would still get higher scores than other countries, except Serbia. The result based on the Netherlands and Serbia was interesting to investigate in detail. The Netherlands would get the lowest score and Serbia would be among top performers on problem-solving if all countries had similar mathematics performance. Similarly, Turkey would be expected to increase their problem-solving scores if they had similar mathematics performance like other countries. Norway and Ireland showed similar performances without and with controlling mathematics performance.

Table 4

Pairwise comparison and adjusted mean differences of problem-solving performance

\begin{tabular}{lcccccccc}
\hline Group & Mean & $\begin{array}{c}\text { Adjusted } \\
\text { Mean }\end{array}$ & Korea & Netherlands & Norway & Ireland & Serbia & Turkey \\
\hline Korea & 561.10 & 511.63 & -- & $25.49^{* *}$ & $5.59^{* *}$ & $20.56^{* *}$ & 1.40 & $19.18^{* *}$ \\
Netherlands & 510.71 & 486.14 & -- & -- & $-19.90^{* *}$ & $-4.93^{* *}$ & $-24.10^{* *}$ & $-6.31^{* *}$ \\
Norway & 503.34 & 506.04 & -- & -- & -- & $14.97^{* *}$ & $-4.20^{*}$ & $13.59^{* *}$ \\
Ireland & 498.34 & 491.07 & -- & -- & -- & -- & $-19.16^{* *}$ & -1.38 \\
Serbia & 473.44 & 510.24 & -- & -- & -- & -- & -- & $17.79^{* *}$ \\
Turkey & 454.49 & 492.45 & -- & -- & -- & -- & -- & -- \\
\hline
\end{tabular}

${ }^{*} p<.01 .{ }^{* *} p<.001$.

\section{Eliminating Possible Effects of Grade Variation in PISA}

PISA aimed to measure how well 15-year-olds were educated to cope with real life problem situations they have never met before. As PISA focus on the age of students when selecting the sample, the grade level of students varies from $7^{\text {th }}$ grade to $12^{\text {th }}$ grade. In order to eliminate the grade effects on the findings of this study, data of $9^{\text {th }}$ and $10^{\text {th }}$ grade students were filtered and the analyses were reconducted. New results are presented in Tables 5,6 and 7. Mean values of student and school variables, standardized regression coefficients, which were used to predict problem-solving scores of students, and mean expected problem-solving differences among countries with or without controlling their mathematics performance were reported. Comparing 
Table 3 and Table 6, the only difference was ESCS, which was found significant in predicting Dutch student's problem-solving performance when grade variation was eliminated. For other tables there were no differences. Therefore, generally, it could be concluded that grade level did not produce an important unwanted variance for the results of this study.

Table 5

Mean of student- and school-level variables

\begin{tabular}{lcccccc}
\hline & Korea & Netherlands & Norway & Ireland & Serbia & Turkey \\
\hline Level-1 & & & & & & \\
$\quad$ Economic, social and cultural status & .01 & .24 & .46 & .17 & -.29 & -1.42 \\
$\quad$ Perseverance & -.09 & -.13 & -.34 & .15 & .20 & .45 \\
$\quad$ Openness for problem-solving & -.37 & -.08 & .18 & -.02 & .46 & .20 \\
$\quad$ Experience with applied math tasks & .40 & .23 & .18 & .18 & -.24 & -.18 \\
$\quad$ Experience with pure math tasks & .43 & .01 & .00 & .16 & -.07 & -.09 \\
Level-2 & & & & & & \\
$\quad$ Class size & 33.60 & 25.24 & 24.68 & 24.95 & 27.99 & 44.05 \\
$\quad$ Proportion of certified teachers & 1.00 & .80 & .89 & 1.00 & .91 & .92 \\
$\quad$ Proportion of teachers with ISCED 5A & 1.00 & .32 & 1.00 & 1.00 & .07 & .93 \\
$\quad$ Quality of school educational resources & .06 & .19 & -.19 & .11 & -.56 & -.38 \\
$\quad$ Extracurricular creative activities & 2.06 & 1.85 & .68 & 1.57 & 1.99 & 1.72 \\
$\quad$ Mathematics extracurricular activities & 4.08 & 1.25 & .99 & 1.83 & 2.77 & 1.75 \\
& & & & & & \\
Problem-solving performance & 561.06 & 513.06 & 503.34 & 499.66 & 475.45 & 455.65 \\
Mathematics performance & 553.73 & 525.48 & 489.37 & 502.76 & 450.54 & 449.33 \\
\hline
\end{tabular}

Table 6

Standardized regression coefficients for problem-solving performance prediction

\begin{tabular}{|c|c|c|c|c|c|c|}
\hline & Korea & Netherlands & Norway & Ireland & Serbia & Turkey \\
\hline \multicolumn{7}{|l|}{ Level-1 } \\
\hline $\begin{array}{l}\text { Economic, social and cultural } \\
\text { status }\end{array}$ & .023 & $.092^{*}$ & $.136^{* * *}$ & $.169^{* * *}$ & $.199^{* * *}$ & $.228^{* * *}$ \\
\hline Perseverance & -.018 & -.050 & $.098^{* *}$ & $.095^{* *}$ & .007 & .073 \\
\hline Openness for problem-solving & $.286^{* * *}$ & $.171^{* * *}$ & $.204^{* * *}$ & $.263^{* * *}$ & $.170^{* * *}$ & $.102^{* *}$ \\
\hline $\begin{array}{l}\text { Experience with applied math } \\
\text { tasks }\end{array}$ & -.030 & $-.175^{* * *}$ & $-.126^{* * *}$ & $-.104^{* *}$ & $-.116^{* *}$ & $-.111^{*}$ \\
\hline Experience with pure math tasks & $.312^{* * *}$ & $.282^{* * *}$ & $.270^{* * *}$ & $.240^{* * * *}$ & $.125^{* *}$ & $.137^{* * *}$ \\
\hline \multicolumn{7}{|l|}{ Level-2 } \\
\hline Class size & .012 & $.235^{*}$ & .053 & $.373^{* * *}$ & .163 & -.124 \\
\hline Proportion of certified teachers & -.234 & .046 & .108 & -.054 & $.386^{* *}$ & -.014 \\
\hline $\begin{array}{l}\text { Proportion of teachers with } \\
\text { ISCED } 5 A\end{array}$ & .191 & $.403^{* * *}$ & NA & $.201^{* * *}$ & .277 & -.113 \\
\hline $\begin{array}{l}\text { Quality of school educational } \\
\text { resources }\end{array}$ & $-.186^{*}$ & -.067 & .030 & .156 & -.037 & $.184^{*}$ \\
\hline Extracurricular creative activities & .068 & -.019 & .073 & -.029 & .152 & .092 \\
\hline $\begin{array}{l}\text { Mathematics extracurricular } \\
\text { activities }\end{array}$ & $.413^{* * *}$ & .127 & .028 & .054 & .160 & $.371^{* * *}$ \\
\hline Explained variance within schools & $22 \%$ & $11 \%$ & $19 \%$ & $22 \%$ & $10 \%$ & $12 \%$ \\
\hline Explained variance between schools & $25 \%$ & $39 \%$ & $03 \%$ & $21 \%$ & $17 \%$ & $27 \%$ \\
\hline
\end{tabular}

Note: NA means Not Applicable (there was zero variation). ${ }^{*} p<.05 .{ }^{* *} p<.01 .{ }^{* * *} p<.001$. 
Arikan: Factors Predicting Creative Problem-Solving Competence in PISA 2012: Evidence from Six ...

Table 7

Pairwise comparison and adjusted mean differences of problem-solving performance

\begin{tabular}{lcccccccc}
\hline Group & Mean & $\begin{array}{c}\text { Adjusted } \\
\text { Mean }\end{array}$ & Korea & Netherlands & Norway & Ireland & Serbia & Turkey \\
\hline Korea & 561.06 & 512.68 & -- & $25.37^{* *}$ & $5.82^{* *}$ & $20.18^{* *}$ & 1.54 & $19.52^{* *}$ \\
Netherlands & 513.06 & 487.31 & -- & -- & $-19.55^{* *}$ & $-5.19^{* *}$ & $-23.83^{* *}$ & $-5.85^{* *}$ \\
Norway & 503.34 & 506.86 & -- & -- & -- & $14.35^{* *}$ & $-4.28^{* *}$ & $13.69^{* *}$ \\
Ireland & 499.66 & 492.50 & -- & -- & -- & -- & $-18.64^{* *}$ & -0.66 \\
Serbia & 475.45 & 511.14 & -- & -- & -- & -- & -- & $17.98^{* *}$ \\
Turkey & 455.65 & 493.16 & -- & -- & -- & -- & -- & - \\
\hline
\end{tabular}

${ }^{*} p<.01 .{ }^{* *} p<.001$.

\section{Discussion and Conclusion}

In the current study, student- and school-level variables that were effective in predicting problem-solving competence of students were identified using data from six countries varying in their problem-solving and mathematics performances in PISA 2012. Additionally, problem-solving performances of these countries were compared controlling their mathematics performance. These findings are expected to contribute to the literature by providing common incentives behind creative problem-solving performance which is a new domain of PISA 2012. In PISA 2012, the creative problemsolving domain focused on general cognitive processes to solve problems that students might face in daily life, rather than problems students may encounter in particular school subjects. Therefore, specific and curriculum based situations were not used as much as possible in the PISA problem-solving domain (OECD 2014a). Enhancing problem-solving competence is important as students who are better problem-solvers are more likely to be successful in other subjects (OECD 2014a).

The results based on student-level variables showed that Walberg's student aptitude variables, openness for problem-solving and perseverance; Walberg's instructional variable and experience with pure mathematics tasks; Walberg's environmental variable and ESCS predicted problem-solving performance positively in general. However, Walberg's instructional variable and experience with applied mathematics tasks predicted problem-solving performance negatively in all countries except Korea. The results based on school-level variables indicated that Walberg's environmental variables, proportion of teachers with ISCED 5A, proportion of certified teachers and class size; and Walberg's instructional variable - mathematics extracurricular activities, predicted problem-solving performance positively in some countries. Quality of school educational resources was found to be related with problem-solving performance in a mixed way. The final analysis, ANCOVA, showed that the problemsolving difference among countries decreased when mathematics performance was controlled. Detailed discussions for student-level and school-level predictors of problem-solving categorized by Walberg's Model as well as the relationship between problem-solving and mathematics scores were reported in the following section. 


\section{Student-Level Variables}

\section{Walberg's Student Aptitude Variables}

Openness for problem-solving and perseverance are motivational and affective factors based on students' willingness and enjoyment to engage in problem-solving even when they face obstacles. In the study, for all countries, whether they are high or low performers, a positive relationship was found between problem-solving performance and openness for problem-solving. This positive association shows that a high score in problem-solving could be a function of being open to problemsolving activities. Students who stated that they were quick to understand things and liked to solve complex problems were more successful. Similarly, perseverance level of students predicted problem-solving scores positively, but only in medium level performing countries (Norway and Ireland). Students who did not give up easily on difficult tasks were more successful in problem-solving. These findings are in line with the existing research on the positive relationship of openness for problemsolving and perseverance on students' performance (Funke, 2010; Kogar, 2015; Mayer, 1998; Perkins \& Shiel, 2014; Scherer \& Gustafsson, 2015). Investing in these two alterable factors could be the key for better problem-solving performance as the definition of problem-solving also includes the motivational component (OECD, 2013a). Therefore, activities that reinforce students' positive attitude towards problemsolving are expected to increase problem-solving scores (Van de Walle, Karp, \& Williams, 2007). Additionally, teaching non-routine problem-solving strategies and ways to handle difficult tasks could enhance students' openness for problem-solving and perseverance levels.

\section{Walberg's Instructional Variables}

Experiences with pure and applied mathematics tasks are opportunity-to-learn indicators. Opportunity to learn (OTL) is defined as student's previous exposure to subject domain content in a school (Schmidt \& Maier, 2009). All stakeholders of the educational system are responsible for giving equal opportunities to the students (Stevens \& Grymes, 1993). OTL was found to be an important predictor of achievement (Meyers, \& Rogers, 2014; Schmidt \& Maier, 2009; Schmidt, Zoido, \& Cogan, 2014). The findings of the study provided mixed results about students' perceived experience with pure and applied mathematics. While experience with pure mathematics tasks predicted problem-solving scores positively in all countries, experience with applied mathematics tasks predicted problem-solving scores negatively in almost all countries (except Korea). Standardized regression coefficients of experience with pure mathematics task were higher than experience with applied mathematics task which could indicate that there would be a positive association between general experience with mathematical tasks and problem-solving scores. These results were based on within country variations. Additionally, when descriptive statistics were investigated in terms of differences between countries, it was observed that higher achieving countries 
had higher mean score on experience with pure and applied mathematics tasks and lower achieving countries had lower mean score on experience with pure and applied mathematics tasks which could indicate a positive relationship.

The negative relationship between experience with applied mathematics tasks and problem-solving scores was somewhat unexpected as PISA claimed to measure problem-solving competence in daily life scenarios with minimum mathematical content. The items that were used to measure experience with applied mathematics tasks asked students how frequently they experienced tasks such as "working out from a train timetable how long it would take someone to get from one place to another". Students were asked to report the frequency, however, the quality of instruction based on these tasks was not measured. The data also did not provide information on how teachers presented pure and applied mathematical tasks to students. Some teachers might only present applied mathematics activities to increase attention of low achieving students, but not of high achieving ones (OECD, 2013c). Teachers might be more focused on only routine problems in applied activities which limit the development of creative problem-solving competence. More comprehensive studies are necessary in order to investigate these relationships.

\section{Walberg's Environmental Variable}

Previous studies generally showed a positive relationship between ESCS and problem-solving or mathematics performance (Akyüz \& Pala, 2010; Alacac1 \& Erbaş, 2010; Bae \& Wickrama, 2015; Perkins \& Shiel, 2014). In PISA 2012 mathematics assessment, socio-economically advantaged students scored on average 78 points higher than disadvantaged students (OECD, 2013d). This study found similar results for the relationship between ESCS and problem-solving performance. For medium and low achieving countries, there was a positive relationship, however for higher achieving countries, positive but not significant association was found. As ESCS in PISA is an indicator of occupational, educational, wealth, cultural, and home educational resources level of parents, it is not easy to alter. What could be done is to provide equal opportunities for students from all socioeconomic statuses. Although this positive relationship did not lead to a cause and effect relationship, socioeconomic status differences, especially in medium and low achieving countries could lead to a differentiation in having high quality teachers and schools. Successful school systems are those which could allocate resources more equitably (OECD, 2013b).

\section{School-Level Variables}

\section{Walberg's Instructional Variables}

Mathematics extracurricular activities showed a positive relationship with problemsolving in the highest and the lowest achieving countries (Korea and Turkey). For other countries, the regression coefficients were positive but nonsignificant. This result indicated that students in schools with a mathematics club, mathematics competition, 
club with a focus on computers/information communication technology, and additional mathematics lessons got higher scores on problem-solving in general. In the study, no relationship was found between problem-solving scores and extracurricular creative activities at school which were based on band, orchestra, choir, school play, school musical, and art club provided in the schools. There was very limited research on the relationship between mathematics extracurricular or extracurricular creative activities and PISA performances. Bove, Marella, and Vitale (2016) reported that they found positive relationship between mathematics extracurricular activities and mathematics performance but they could not find any relationship between extracurricular creative activities and mathematics performance. As mathematics extracurricular and extracurricular creative activities scores were derived from principals' reports about school activities, we did not know how these activities were conducted. Investment in these mathematics clubs, especially in low achieving schools, could lead to higher student performances. However, the way these clubs function is very important. Performing carefully designed problem-solving activities in these clubs could increase effectiveness of club time which could lead to better student outcomes. As PISA also measures creativity in problem-solving assessment, extracurricular activities that foster non-routine problem-solving skills would be beneficial. These activities should be prepared according to the students' cognitive levels in order to promote their conceptual understanding.

\section{Walberg's Environmental Variables}

In the Netherlands and Ireland, proportion of teachers with ISCED 5A, equivalent of university degree, and in Serbia proportion of certified teachers predicted problemsolving performances positively. These two variables were indicators of better educated teachers. Ma and $\mathrm{Ma}$ (2014) reported mixed results for the relationship between teacher quality and PISA performance. Descriptive statistics showed that countries which had a nonsignificant relationship had mean values very close to one. Such values indicated that in these countries almost all teachers had these degrees or certifications which limited the variation. If there would be more variation in terms of degree level, significant relationships could be found. Still, investing in both pre-service and inservice teacher education is expected to increase problem- solving performances.

Class size and quality of school educational resources were found to be related with problem-solving performance in a mixed way. Only in the Netherlands and Ireland, there was a positive association between class size and problem-solving scores. As both countries had the smallest mean in class size (25.18 and 24.90, respectively), this result should be analyzed cautiously. For other countries, no association was found. There are many studies that could also not find significant relationship between class size and performance (Cordero, Crespo, \& Santin, 2010; Fuchs \& Wößmann 2007; Sousa, Park, \& Armor, 2012). School educational resources predicted student performance positively in Turkey and negatively in Korea. Index of quality of school 
educational resources was related to science laboratory equipment, instructional materials, computers for instruction, internet connectivity, computer software for instruction, and library materials at school. Low achieving countries such as Turkey had higher inequality in allocating educational resources. Better schools have more resources and disadvantaged students have problems in reaching better schools, which also creates an achievement gap. Distributing resources more equitably among advantaged and disadvantaged schools could lead to higher performance.

\section{The Relationship between Problem-Solving and Mathematics Performance}

PISA reported in their validity analysis that problem-solving domain was differentiated from mathematics and other domains. The score difference between students and schools in problem-solving performance did not only come from differences in mathematics performance (OECD, 2014a). Problem-solving and mathematics country rankings were not the same. Korea, Norway and Serbia performed better, and the Netherlands, Ireland and Turkey performed worse than expected on problem-solving compared to their mathematics performance. However, in some respect there was an important relationship between problem-solving and mathematics performances. This study showed that if all students' mathematics performance were similar, the problem-solving performance difference among countries would be smaller. Therefore, increasing students' mathematics performances, especially in low achieving countries could increase problem-solving performances indirectly.

This study is novel in investigating predictors of the creative problem-solving competence. As this competence started being measured comprehensively for the first time in PISA 2012, related research is limited. PISA provides data to compare findings across countries. This study found common as well as country specific predictors of problem-solving. Although each country has their own characteristics, common factors show us important clues to increase problem-solving competence, which is important to be successful in modern society. As PISA continues to administer separate creative problem-solving assessment, more studies, including longitudinal ones, will be conducted.

\section{Implications}

The current study has several implications. The findings of the study were based on relationships among variables which did not mean causation. However, change in these predictive variables might create a change in problem-solving abilities. Therefore, implications were provided with this probabilistic approach.

Activities that would reinforce students' positive attitude towards problem-solving, or that encourage students to engage with more problems would be beneficial. These activities could be part of instruction or could be provided as term projects. 
There is an opportunity to reduce the gap between and within countries. Increasing experiences with mathematics tasks, especially for those who have limited opportunities, would increase problem-solving abilities. Extracurricular mathematics activities that foster non-routine problem-solving skills would be increased in schools.

Considering the relationship between mathematics and problem-solving performances, there is a possibility that increasing students' mathematics ability might increase problem-solving performances. Therefore, emphasis given to mathematics education by educators should continue.

\section{References}

Alacac1, C., \& Erbaş, A. K. (2010). Unpacking the inequality among Turkish schools: Findings from PISA 2006. International Journal of Educational Development, 30(2), 182-192. https:// doi.org/10.1016/j.ijedudev.2009.03.006

Akyüz, G., \& Pala, N. M. (2010). The effect of student and class characteristics on mathematics literacy and problem solving in PISA 2003. Ilköğretim Online, 9(2), 668-678.

Areepattamannil, S. (2014). International Note: What factors are associated with reading, mathematics, and science literacy of Indian adolescents? A multilevel examination. Journal of Adolescence, 37(4), 367-372. https://doi.org/10.1016/j.adolescence.2014.02.007

Aztekin, S., \& Yilmaz, H. B. (2014). The effects of human and material resources on students' math achievement in 45 countries. Problems of Education in the 21st Century, 62, 8-20.

Bae, D., \& Wickrama, K. A. S. (2015). Family Socioeconomic Status and Academic Achievement Among Korean Adolescents Linking Mechanisms of Family Processes and Adolescents' Time Use. The Journal of Early Adolescence, 35, 1014-1038. https://doi. org/10.1177/0272431614549627

Breton, T. R. (2014). Evidence that class size matters in 4th grade mathematics: An analysis of TIMSS 2007 data for Colombia. International Journal of Educational Development, 34, 51-57. https://doi.org/10.1016/j.ijedudev.2013.04.003

Bove, G., Marella, D., \& Vitale, V. (2016). Influences of School Climate and Teacher's Behavior on Student's Competencies in Mathematics and the Territorial Gap between Italian Macro-areas in PISA 2012. Journal of Educational, Cultural and Psychological Studies (ECPS Journal), 1(13), 63-96. https://doi.org/10.7358/ecps-2016-013-bove

Cohen, J. (1988). Statistical power analysis for the behavioral sciences (2nd ed.). Mahwah, NJ: Lawrence Erlbaum.

Cordero, J. M., Crespo, E., \& Santin, D. (2010). Factors affecting educational attainment: Evidence from Spanish PISA 2006 results. Regional and Sectorial Economic Studies, 10(3), $55-76$.

Fiore, B. (2015). Improving Excellence in Schools: Evidence from the Italian OECD-PISA 2012 Data. Italian Journal of Sociology of Education, 7(2), 126-156. 
Arikan: Factors Predicting Creative Problem-Solving Competence in PISA 2012: Evidence from Six ...

Fuchs, T., \& Wößmann, L. (2007). What accounts for international differences in student performance? A re-examination using PISA data. Empirical Economics, 32, 433-464. https://doi.org/10.1007/s00181-006-0087-0

Funke, J. (2010). Complex problem solving: A case for complex cognition? Cognitive Processing, 11, 133-142. https://doi.org/10.1007/s10339-009-0345-0

Guèvremont, A., Findlay, L., \& Kohen, D. (2014). Organized Extracurricular Activities: Are In-School and Out-of-School Activities Associated with Different Outcomes for Canadian Youth? Journal of School Health, 84(5), 317-325. https://doi.org/10.1111/josh.12154

Hattie, J. (2005). The paradox of reducing class size and improving learning outcomes. International Journal of Educational Research, 43, 387-425. https://doi.org/10.1016/j. ijer.2006.07.002

Hox, J. (2010). Quantitative methodology series. Multilevel analysis techniques and applications. Mahwah, NJ: Lawrence Erlbaum Associates.

International Association for the Evaluation of Educational Achievement (IEA). (2013). IDB Analyzer [Computer software]. Hamburg, Germany.

Kogar, H. (2015). Examination of Factors Affecting PISA 2012 Mathematical Literacy through Mediation Model. Egitim ve Bilim, 40(179), 45-55.

Ma, V. J., \& Ma, X. (2014). A comparative analysis of the relationship between learning styles and mathematics performance. International Journal of STEM Education, 1(1), 1-13. https:// doi.org/10.1186/2196-7822-1-3

Mayer, R.E. (1998). Cognitive, metacognitive, and motivational aspects of problem solving. Instructional Science, 26, 49-63. https://doi.org/10.1023/A:1003088013286

Meyers, H. W., \& Rogers, J. D. (2014, April). Equity of Opportunity to Learn, Spending and Student Achievement: A Statewide Analysis. Paper presented at American Educational Research Association Conference, Philadelphia, USA.

Muthén, L. K., \& Muthén, B.O. (2015). Mplus User’s Guide (7th ed.). Los Angeles, CA: Muthén \& Muthén.

OECD (1999). Classifying Educational Programmes: Manual for ISCED-97 Implementation in OECD Countries. Paris, France: OECD Publishing.

OECD (2013a). PISA 2012 Assessment and Analytical Framework: Mathematics, Reading, Science, Problem Solving and Financial Literacy. Paris, France: OECD Publishing.

OECD (2013b). PISA 2012 Results: What Makes Schools Successful? Resources, Policies and Practices (Volume IV). Paris, France: OECD Publishing.

OECD (2013c). PISA 2012 Results: Ready to Learn: Students'Engagement, Drive and Self-Beliefs (Volume III). Paris, France: OECD Publishing.

OECD (2013d). PISA 2012 Results: Excellence Through Equity: Giving Every Student the Chance to Succeed (Volume II). Paris, France: OECD Publishing.

OECD (2014a). PISA 2012 Results: Creative Problem Solving: Students'Skills in Tackling RealLife Problems (Volume V). Paris, France: OECD Publishing.

OECD (2014b). PISA 2012 Technical Report. Paris, France: OECD Publishing.

Perkins, R., \& Shiel, G. (2014). Problem Solving in PISA: The Results of 15-year-olds on the Computer-based Assessment of Problem Solving in PISA 2012. Dublin: Educational Research Centre. Retrieved from http://www.erc.ie/documents/p12psreport.pdf. 
Scherer, R., \& Gustafsson, J. E. (2015). The relations among openness, perseverance, and performance in creative problem solving: A substantive-methodological approach. Thinking Skills and Creativity, 18, 4-17. https://doi.org/10.1016/j.tsc.2015.04.004

Schmidt, W. H., \& Maier, A. (2009). Opportunity to learn. In G. Sykes, B. Schneider, \& D. N. Plank (Eds.), Handbook of education policy research (pp. 541-559). New York, NY: Rutledge.

Schmidt, W. H., Zoido, P., \& Cogan, L. (2014). Schooling Matters: Opportunity to Learn in PISA 2012. OECD Education Working Papers, No. 95. Paris, France: OECD Publishing. https:// doi.org/10.1787/5k3v0hldmchl-en

Sousa, S., Park, E. J., \& Armor, D. J. (2012). Comparing effects of family and school factors on crossnational academic achievement using the 2009 and 2006 PISA surveys. Journal of Comparative Policy Analysis: Research and Practice, 14(5), 449-468. https://doi.org/10. $\underline{1080 / 13876988.2012 .726535}$

Stevens, F., \& Grymes, J. (1993). Opportunity to learn: Issues of equity for poor and minority students. Washington, DC: US Department of Education, National Center for Education Statistics.

Tabachnick, B. G., \& Fidell, L. S. (2013). Using Multivariate Statistics. Essex, England: Pearson Education.

Walberg, H. J. (1981). A psychological theory of educational productivity. In F. H. Farley, \& N. Gorden (Eds.), Psychology and education (pp. 81-108). Berkeley, CA: McCutchan.

Walberg, H. J. (1984). Improving the productivity of America's schools. Educational Leadership, 41(8), 19-27.

Walberg, H. J. (2004). Improving educational productivity: An assessment of extant research. The LSS Review, 3(2), 11-14.

Van de Walle, J. A., Karp, K. S., \& Williams, J. M. B. (2007). Elementary and middle school mathematics. Teaching development. Boston: Pearson.

\section{Serkan Arikan}

Mugla Sitki Kocman University, Institute of Educational Sciences

Kotekli, Mentese, Mugla, Turkey

serkanarikan@mu.edu.tr 


\section{Čimbenici predviđanja kompetencije kreativnog rješavanja problema - PISA 2012: Dokazi iz šest zemalja}

\section{Sažetak}

PISA mjeri razinu spremnosti 15-godišnjih učenika za izazove na koje mogu naići u budućnosti te vrednuje njihovu sposobnost promišljanja i primjene znanja rješavanja svakodnevnih problema. PISA ne samo da mjeri specifične sadržaje poput matematike nego mjeri i općenita područja poput kreativnoga rješavanja problema. Kreativno rješavanje problema novi je koncept koji je primijenila PISA 2012, a identificiranje prediktora za rješavanje problema u zemljama s niskom, srednjom i visokom razinom uspješnosti nova je i vrlo važna tema. Ovo istraživanje uglavnom se bavi učenicima i karakteristikama škola za učinkovito predviđanje vještina rješavanja problema. Nadalje, istražena je razlika u uspješnosti rješavanja problema među zemljama pod uvjetom slične uspješnosti u području matematike. Ovo istraživanje uključivalo je sve učenike koji su sudjelovali u PISA 2012 iz Koreje, Nizozemske, Irske, Srbije i Turske. Smatra se da navedenih šest zemalja predstavlja dobar spektar svih zemalja sudionika u smislu kreativnoga rješavanja problema $i$ postignuća u matematici. Rezultati višerazinske regresijske analize pokazali su da među varijablama učenika otvorenost za rješavanje problema $i$ iskustvo s čistim matematičkim zadatcima pozitivno predviđa postignuća u rješavanju problema u svim zemljama. Društveno-ekonomski status pozitivno predviđa postignuća u rješavanju problema u zemljama sa srednjom ili niskom razinom uspješnosti. Iznenaduje da iskustvo sa zadatcima primijenjene matematike negativno predvida postignuća u rješavanju problema u svim zemljama izuzev Koreje. Varijable škole ne ukazuju na sustavni obrazac u predviđanju uspješnosti u rješavanju problema. Među varijablama škole, izvannastavne aktivnosti iz matematike, udio nastavnika s ISCED 5A, udio licenciranih nastavnika i veličina razreda pozitivno predvidaju uspješnost u rješavanju problema u nekim zemljama. Rezultati ANCOVA testa pokazuju da se razlika u rješavanju problema među zemljama smanjuje kada se kontroliraju postignuća u matematici.

Ključne riječi: kompetencija rješavanja problema; matematičko postignuće; PISA 2012; višerazinska analiza. 


\section{Uvod}

Kako svijet postaje sve povezaniji, ostvarenje nacionalnih ciljeva i standarda postaje nedovoljno za natjecanje s razvijenim zemljama. Usporedba postignuća učenika, samih učenika i karakteristika škola na međunarodnoj razini važna je za vrednovanje uspjeha. Program međunarodnog ispitivanja znanja i vještina (PISA) osigurava vrijedne podatke za usporedbe postignuća u području matematike, čitanja i prirodnih znanosti. PISA odnedavno pruža detaljne informacije o učeničkoj kompetenciji kreativnoga rješavanja problema. Rješavanje problema ključan je čimbenik uspješnosti u suvremenom društvu. Korištenjem podataka koje nudi PISA moguće je identificirati prediktore kompetencije rješavanja problema. Identificirajući ključne čimbenike koji su povezani s rješavanjem problema, zemlje imaju mogućnosti istraživati upravo te čimbenike. U ovome istraživanju, čimbenici su identificirani koristeći se PISA 2012 podatcima iz šest zemalja (dvije visoko, dvije srednje i dvije zemlje niskoga postignuća $\mathrm{s}$ obzirom na rezultate vrednovanja rješavanja problema). Nadalje, detaljne analize provedene su kako bi se razumjele razlike među tim zemljama u rješavanju problema kad bi imale slična postignuća u području matematike prema PISA rezultatima.

U današnjem svijetu rada i života povećava se gotovo svakodnevna nužnost rješavanja problema na neuobičajen način. Jedna od posljedica toga jest da se mijenja i naglasak na očekivanim obrazovnim procesima i ishodima. Ciljevi su obrazovnih sustava pripremiti učenike za život sutrašnjice razvijajući kod njih sposobnost da rješavaju složene i neuobičajene zadatke. PISA sustav te sposobnosti, posebice kompetenciju kreativnoga rješavanja problema, mjeri kao posebno područje vrednovanja. Kompetencija rješavanja problema definira se u PISA 2012 kao vrednovanje (OECD, 2013a, str. 122):

sposobnosti pojedinca da se uključi u kognitivne procese kako bi razumio $i$ riješio problemske situacije a kada rješenje nije odmah očito. Podrazumijeva volju za angažiranjem u takve situacije da bi se ostvario potencijal osobe kao konstruktivnoga i refleksivnoga građanina.

Nudeći posebno područje: rješavanje problema, cilj PISA-e bio je izmjeriti koliko su dobro 15-godišnjaci obrazovani u smislu suočavanja sa stvarnim životnim problemima s kojima se do tada nisu susretali. PISA vrednovanje kreativnoga rješavanja problema naglasak stavlja na kognitivne procese koji se aktiviraju prilikom rješavanja problema, za razliku od rješavanja problema vezanoga uz specifičan školski predmet. Elementi rješavanja problema ne zahtijevaju nikakvu stručnost u sadržaju (OECD, 2014a). Predmetno specifični zadatci vezani uz rješavanje problema također se mjere u drugim područjima PISA vrednovanja, primjerice u području matematike (OECD, 2013a). PISA je izvijestila o povezanim analizama valjanosti koje su pokazale da rješavanje problema tvori područje neovisno o matematici i drugim područjima (OECD, 2014a).

PISA vrednovanje područja rješavanja problema provedeno je prvi put u 2003. u pisanome obliku. U 2012. godini rješavanje problema provedeno je putem računalnog 
vrednovanja u izazovnijem i interaktivnom formatu. To je bio nov način mjerenja kompetencije rješavanja problema kod 15-godišnjaka. Važno je napomenuti da su neke zemlje bile uspješnije ili manje uspješne od očekivanoga u području rješavanja problema u odnosu na matematička postignuća. Primjerice, među zemljama s visokim, srednjim i niskim postignućima, Koreja, Norveška i Srbija postigle su više rezultate od očekivanih u području rješavanja problema. Međutim, među zemljama s visokim, srednjim i niskim postignućima, Nizozemska, Irska i Turska postigle su niže rezultate od očekivanih u području rješavanja problema (OECD, 2014a). Stoga se od određivanja prediktora postignuća u rješavanju problema očekuje davanje indikacija o poticajima koji stoje iza razlika u postignućima. Proučavanje korelacija kreativnoga rješavanja problema koje je izmjerila PISA 2012 nova je tema koja će doprinijeti obrazovnoj literaturi.

\section{Čimbenici koji predviđaju razlike u postignućima u rješavanju problema}

Walberg $(1981,1984,2004)$ predlaže teorijski okvir (Model obrazovne produktivnosti) koji se često upotrebljava u istraživanjima postignuća koja istražuju prediktore postignuća. $U$ tom modelu identificirane su tri skupine čimbenika koje se povezuju s postignućem učenika: varijable učenikove sposobnosti, varijable okoliša i varijable poučavanja. Walbergov model i hijerarhijska struktura PISA-e (razina učenika i razina škole) usmjeravali su ovo istraživanje u organizaciji i izboru prediktora za postignuća u rješavanju problema. Varijable sposobnosti učenika povezane su s motivacijom učenika i samopoimanjem. Varijable okoliša uključuju dom, razred i vršnjake. Taj čimbenik povezan je sa sociološkim-psihološkim ozračjem doma, razreda i grupe vršnjaka. Varijable poučavanja uključuju kvantitetu, vrijeme i kvalitetu poučavanja. Taj čimbenik ukazuje na aspekte poučavanja koji utječu na učenje.

Varijable na razini učenika koje bi mogle biti prediktori postignuća u rješavanju problema u PISA-i su ekonomski, socijalni i kulturni status, upornost i otvorenost za rješavanje problema, iskustvo $s$ čistim matematičkim i primijenjenim matematičkim zadatcima u školi. Među tim varijablama, upornost i otvorenost za rješavanje problema izdvojeni su kao predstavnici varijable učenikovih sposobnosti; ekonomski, socijalni i kulturni status izdvojeni su kao varijable okoliša; iskustvo s čistim matematičkim i primijenjenim matematičkim zadatcima u školi kategorizirani su kao varijable poučavanja prema Walbergovu modelu. Upornost i otvorenost za rješavanje problema motivacijski su i afektivni čimbenici učenikove volje za bavljenjem i rješavanjem problema. Upornost i otvorenost za rješavanje problema povezana je $s$ kompetencijom rješavanja problema (Funke, 2010; Kogar, 2015; Mayer, 1998; Perkins i Shiel, 2014; Scherer i Gustafsson, 2015). Ekonomski, socijalni i kulturni status (ESCS) je profesionalni, obrazovni, materijalni i kulturni pokazatelj obitelji. Mnoga istraživanja ukazala su na pozitivne odnose između ESCS-a i rješavanja problema ili postignuća u matematici (Akyüz i Pala, 2010; Alacacı i Erbaş, 2010; Bae i Wickrama, 2015; Perkins i 
Shiel, 2014). Iskustva sa zadatcima iz čiste i primijenjene matematike u školi indikatori su prilike za učenje koji ukazuju na značajnu povezanost s postignućima u PISA-i (Schmidt, Zoido, i Cogan, 2014).

Varijable razine škole koje bi mogle biti prediktori postignuća u rješavanju problema u PISA mjerenjima su veličina razreda, udio licenciranih nastavnika, udio nastavnika s ISCED 5A (International Standard Classification of Education), kvaliteta obrazovnih resursa škole, izvannastavne kreativne aktivnosti u školi, izvannastavne aktivnosti iz matematike u školi. U Walbergovu modelu, veličina razreda, udio licenciranih nastavnika, udio nastavnika s ISCED 5A i kvaliteta obrazovnih resursa u školi predstavljaju varijable okoliša. Izvannastavne kreativne aktivnosti u školi i izvannastavne aktivnosti iz matematike u školi kategorizirane su kao varijable poučavanja prema Walbergovu modelu. Smatra se da veličina razreda utječe na uspješnost učenika (OECD, 2013b). Međutim, rezultati su bili različiti s obzirom na odnose između veličine razreda i uspješnosti učenika (Breton, 2014; Hattie, 2005). Udio licenciranih nastavnika i udio nastavnika s ISCED 5A indikatori su kvalitete nastavnika u školi. ISCED 5A jedna je od klasifikacija svih studijskih programa koja je jednaka sveučilišnoj diplomi (OECD, 1999). Bolja kvaliteta obrazovnih resursa škole povezana je u nekim zemljama s uspjehom učenika (Areepattamannil, 2014). Neki znanstvenici ukazali su na to da se učinkovitost kvalitetnih obrazovnih resursa razlikuje od zemlje do zemlje (Aztekin i Yilmaz, 2014). Izvannastavne kreativne aktivnosti u školi i izvannastavne aktivnosti iz matematike u školi indikatori su aktivnosti koje se održavaju u školi. Sudjelovanje u izvannastavnim aktivnostima rezultira pozitivnim i negativnim ishodima (Guèvremont, Findlay, i Kohen, 2014). Fiore (2015) izvješćuje da postoji slaba povezanost između izvannastavnih aktivnosti iz matematike i rezultata u matematici.

\section{Istraživanje}

Od škola se očekuje ne samo da razviju i realiziraju kurikulne ciljeve nego i da razviju sposobnosti učenika za rješavanjem problema. Učenici bi morali biti opremljeni boljim vještinama rješavanja problema. Kako bi to ostvarili, nastavnici bi morali biti informirani o učenicima i karakteristikama škole koje su učinkovite u predviđanju vještina rješavanja problema. Istraživanje značajnih prediktora rješavanja problema u zemljama s visokim, srednjim i niskim postignućima trebalo bi ukazati na neke znakove. OECD je izvijestio o tome da neke zemlje imaju niža postignuća od očekivanih u rješavanju problema u usporedbi s rezultatima iz matematike (OECD, 2014a). Stoga je bitno istražiti koja bi bila očekivana postignuća u rješavanju problema za te zemlje. Ovo istraživanje doprinosi literaturi tako da identificira korelacije postignuća u rješavanju problema. Istraživačka pitanja su sljedeća:

1. Koji čimbenici učenika i razine škole predviđaju učenikova postignuća u rješavanju problema u zemljama s visokim, srednjim i niskim postignućima $u$ PISA 2012?

2. Koje bi bile razlike u postignućima u rješavanju problema među tim zemljama kada bi učenici imali slična postignuća u matematici? 
Hipoteze su sljedeće:

1. Mogli bismo predvidjeti postignuća učenika u rješavanju problema u zemljama s visokim, srednjim i niskim postignućima koristeći se čimbenicima učenika i razine škole.

2. Postoje razlike u postignućima u rješavanju problema među tim zemljama čak i kad bi učenici imali slična postignuća u matematici.

\section{Metodologija}

\section{Uzorak}

Podatci u ovome istraživanju dobiveni su iz PISA 2012 baze podataka. Ciljna populacija PISA-e su 15-godišnji učenici iz zemalja sudionica. Ovo istraživanje uključilo je sve učenike iz Koreje, Nizozemske, Norveške, Irske, Srbije i Turske koji su sudjelovali u PISA 2012. Tih šest zemalja odabrano je s obzirom na to da su Koreja i Nizozemska imale rezultate srednje vrijednosti više od prosjeka. Norveška i Irska imale su prosječne rezultate srednje vrijednosti, a Srbija i Turska imale su rezultate srednje vrijednosti niže od prosjeka kod vrednovanja vještine rješavanja problema. Nadalje, Koreja, Norveška i Srbija postigle su više rezultate u rješavanju problema od očekivanih u usporedbi s rezultatima iz matematike, a Nizozemska, Irska i Turska postigle su niže rezultate od očekivanih. Stoga je tih šest zemalja određeno kao reprezentativni uzorak iz spektra zemalja sudionica (OECD, 2014a).

U PISA 2012 koristila se dvofazna stratifikacija uzorka. U prvoj fazi izabrane su škole s vjerojatnošću proporcionalnom broju podobnih 15-godišnjaka u školi. Najmanje 150 škola odabrano je iz svake zemlje. U drugoj fazi, učenici iz odabranih škola uzorkovani su s jednakom vjerojatnošću. Broj učenika uzorkovanih iz svake škole bio je oko 35 (OECD, 2013a). Podatci iz PISA 2012 govore da je 5033 učenika iz Koreje, 4460 učenika iz Nizozemske, 4686 učenika iz Norveške, 5016 učenika iz Irske, 4684 učenika iz Srbije i 4848 učenika iz Turske bilo raspoloživo. Broj učenica i učenika bio je gotovo isti za sve zemlje. Učenici koji su bili podvrgnuti PISA 2012 uglavnom su bili učenici 9-ih i 10-ih razreda (vidi Tablicu 1).

Tablica 1

\section{Mjerenja}

PISA 2012 dobiva podatke o postignućima učenika u rješavanju problema putem testa rješavanja problema; o karakteristikama učenika putem upitnika za učenike; o karakteristikama škole putem upitnika za školu (upućeno ravnateljima). PISA 2012 vrednovanje rješavanja problema provedeno je putem računala. Zadatci za vrednovanje rješavanja problema povezani su s izvanškolskim situacijama s kojima se učenici mogu susresti u svakodnevnom životu poput tehnoloških naprava (daljinski upravljač, sat, itd.) ili s nepoznatim mjestima (promet, dezorijentiranost itd.). Ti su zadatci bili što je moguće manje povezani sa sadržajem ili informacijama vezanima uz kurikul. Tekst je bio kratak i lagan za čitanje, a kod aritmetičkih operacija kalkulator 
je bio ponuđen na ekranu. Zadatci za rješavanje problema pripremljeni su uzimajući $\mathrm{u}$ obzir tri različita aspekta: prirodu problemske situacije koja je povezana s time je li dana ili nije sva informacija potrebna za rješavanje problema; proces rješavanja problema koji je povezan s glavnim kognitivnim procesima uključenima u određenom zadatku poput istraživanja i razumijevanja, predstavljanja i formuliranja, planiranja i izvođenja, praćenja i promišljanja; problemski sadržaj koji je povezan s time uključuje li scenarij tehnološki alat ili ne i uključuje li svakodnevni scenarij osobno ili društveno okruženje. Ukupno 42 zadatka unutar 16 jedinica grupirana su u 4 skupine koje su dane učenicima kako bi se izmjerila njihova postignuća u rješavanju problema $(\mathrm{OECD}$, 2014a).Zadatci za rješavanje problema bili su ponuđeni na sljedećoj mrežnoj stranici: http://www.oecd.org/pisa/pisaproducts/pisa2012problemsolvingquestions.htm.PISA nudi pet mogućih rezultata za svakog učenika koji predstavlja učenikovo postignuće u rješavanju problema koristeći se višestrukim pripisivanjem podataka. Ti rezultati procijenjeni su koristeći se teorijom odgovora na zadatke (Eng. Item Response Theory) (IRT). Rezultati sposobnosti dobiveni iz IRT analize pretvoreni su u moguće rezultate postavljajući OECD rezultat srednje vrijednosti na 500 i standardne devijacije na 100. Ukupna pouzdanost za zadatke rješavanja problema bila je 0,88 (OECD, 2014b).

U ovome istraživanju, ekonomski, društveni i kulturni status (ESCS), upornost i otvorenost za rješavanje problema, iskustvo s čistim matematičkim zadatcima i zadatcima primijenjene matematike $u$ školi koristili su se kao varijable na razini učenika. Indeks ESCS prema PISA-i bio je kombinacija najvišeg statusa zanimanja roditelja, najviše obrazovne razine roditelja, obiteljskog bogatstva, kulturnog vlasništva i obrazovnih resursa kod kuće (OECD, 2014b). Indeks upornosti procijenjen je prema PISA-i kao slaganje učenika sa sljedećim tvrdnjama: „kada se suočim s problemom, lako odustanem; odgodim teže probleme; ostanem zainteresiran za zadatke koje započnem; nastavim raditi na zadatcima dok sve ne bude savršeno; kada se suočim s problemom, napravim više nego što se od mene očekuje“. Indeks otvorenosti za rješavanje problema prema PISA-i nastao je na osnovi slaganja učenika sa sljedećim tvrdnjama: „Mogu se nositi s puno informacija; Brzo razumijem stvari; Tražim objašnjenja za stvari; Lako povezujem podatke; Volim rješavati složene probleme“ (OECD, 2014a). Kako bi se izmjerilo iskustvo s primijenjenim zadatcima iz matematike i čistim matematičkim zadatcima u školi, koristila se perspektiva učenika o učestalost iskustava s takvim zadatcima u školi, npr. „iz rasporeda polazaka i dolazaka vlakova trebam procijeniti koliko vremena bi mi trebalo od jednog mjesta do drugoga" $i$ „rješavanje jednadžbe poput $6 \mathrm{x}^{2}+5=29$ ” (OECD, 2014b). Te ljestvice podataka napravljene su preračunavanjem zadataka primjenom IRT-a. Srednja vrijednost pouzdanosti za ESCS bila je 0,65; srednja vrijednost pouzdanosti za upornost bila je 0,80 ; srednja vrijednost pouzdanosti za otvorenost za rješavanje problema bila je 0,82 ; srednja vrijednost pouzdanosti za iskustvo $s$ čistim matematičkim zadatcima bila je 0,92 ; srednja vrijednost pouzdanosti za iskustvo s primijenjenim matematičkim zadatcima bila je 0,77 (OECD, 2014b). 
Varijable vezane uz škole u ovome istraživanju bile su veličina razreda, udio licenciranih nastavnika, udio nastavnika s ISCED 5A, kvaliteta školskih obrazovnih resursa, izvannastavne kreativne aktivnosti u školi, izvannastavne aktivnosti iz matematike $u$ školi. PISA određuje veličinu razreda brojem učenika u razredu. Udio licenciranih nastavnika i udio nastavnika s ISCED 5A prema PISA-i upućuje na kvalitetu nastavnika u školi. Indeks kvalitete obrazovnih resursa u školi PISA određuje koristeći se čimbenicima poput: nedostatak ili neprikladnost laboratorijskog materijala; nedostatak ili neprikladnost nastavnog materijala; nedostatak ili neprikladnost računala za nastavu; nedostatak ili neprikladnost mrežne povezanosti; nedostatak ili neprikladnost računalnog softvera za poučavanje; nedostatak ili neprikladnost knjižničnih materijala. Visoki rezultat za kvalitetu školskih obrazovnih resursa upućuje na to da škola ima bolje obrazovne resurse. Indeks izvannastavnih kreativnih aktivnosti u školi dobiven je u PISA-i na osnovi broja školskih aktivnosti poput benda, orkestra ili zbora; školske predstave ili školskog mjuzikla, umjetničkog kluba ili umjetničkih aktivnosti. Indeks izvannastavnih matematičkih aktivnosti u školi prema PISA-i određuje se na osnovi školskih aktivnosti poput matematičkog kluba; natjecanja iz matematike, računalnog ili ICT kluba; dodatne nastave matematike (OECD, 2013b). Ljestvica indeksa za kvalitetu školskih obrazovnih resursa načinjena je preračunavanjem elemenata prema IRT. Indeks srednje vrijednosti pouzdanosti bio je 0,81 (OECD, 2014b). Varijable škole izračunate su na osnovi broja povezanih čimbenika.

\section{Analiza podataka}

Kako bismo dobili odgovor na prvo istraživačko pitanje korištenjem podataka iz šest zemalja (Koreja, Nizozemska, Norveška, Irska, Srbija i Turska), identificirani su prediktori za postignuća u rješavanju problema kod učenika i na razini škole. $S$ obzirom na to da su podatci imali hijerarhijsku strukturu u kojoj su učenici uvršteni u škole, napravljena je višerazinska regresijska analiza (random intercepts model) za svaku zemlju posebno. Značajni su čimbenici dobiveni i objašnjeni, a izračunato je odstupanje $u$ vještini rješavanja problema unutar i među školama. $U$ analizi, varijable na razini učenika (ESCS, upornost i otvorenost za rješavanje problema, iskustvo s čistim matematičkim i primijenjenim matematičkim zadatcima u školi), varijable na razini škole (veličina razreda, udio licenciranih nastavnika, udio nastavnika s ISCED $5 \mathrm{~A}$, kvaliteta školskih obrazovnih resursa, izvannastavne kreativne aktivnosti u školi, izvannastavne matematičke aktivnosti u školi) bile su nezavisne varijable. Pet mogućih rezultata učenika za postignuća u rješavanju problema činile su zavisne varijable. Višerazinske analize bile su primijenjene koristeći se MPLUS 7.4. MPLUS program koristio se s obzirom na to da može provesti višerazinske analize uzimajući u obzir pet mogućih rezultata učenika u rješavanju problema koje nalazimo u PISA izvješću (Muthen i Muthen, 2015).

$\mathrm{Za}$ odgovor na drugo istraživačko pitanje napravljena je analiza kovarijance (ANCOVA) gdje je postignuće u matematici bilo kovarijan, postignuće u rješavanju 
problema bila je zavisna varijabla, a zemlje u istraživanju bile su varijabla za grupiranje. Stoga je kontroliranjem postignuća u matematici identificirano očekivano postignuće kod rješavanja problema u tim zemljama. ANCOVA rezultati koristili su se za identificiranje očekivanih postignuća kod rješavanja problema među tim zemljama ako su imali slična postignuća u matematici. ANCOVA je provedena koristeći se SPSS 20.0 programom.

\section{Rezultati}

\section{Deskriptivna statistika}

U ovome dijelu prikazane su srednje vrijednosti nezavisnih i zavisnih varijabli (vidi Tablicu 2). Vrijednosti su procijenjene uz pomoć programa IDB Analyzer kako bi se odredile težine uzorkovanja na osnovi procedure uzorkovanja koja se koristila za PISA (International Association for the Evaluation of Educational Achievement, 2013). Za ESCE, Norveška i Turska imale su najveću i najnižu srednju vrijednost. Najvišu i najnižu srednju vrijednost za upornost i veličinu razreda imale su pojedinačno Turska i Norveška. Srbija je imala najvišu, a Koreja najnižu srednju vrijednost za otvorenost za rješavanje problema. Za iskustva sa zadatcima primijenjene matematike, Koreja i Srbija imale su pojedinačno najvišu i najnižu srednju vrijednost. Za iskustva s čistim matematičkim zadatcima Koreja je imala najvišu, a Turska najnižu srednju vrijednost. Najvišu srednju vrijednost za udio licenciranih nastavnika imale su Koreja i Irska, a Norveška je imala najnižu srednju vrijednost. Za udio nastavnika s ISCED 5A, Koreja, Norveška i Irska imale su najvišu srednju vrijednost, a Srbija je imala najnižu srednju vrijednost. Što se tiče kvalitete obrazovnih resursa, Nizozemska i Srbija imale su pojedinačno najvišu i najnižu srednju vrijednost. Za izvannastavne aktivnosti i izvannastavne matematičke aktivnosti Koreja je imala najvišu srednju vrijednost, a Norveška najnižu srednju vrijednost.

S obzirom na postignuća u rješavanju problema i postignuću u matematici, Koreja je imala najvišu srednju vrijednost, a Turska najnižu srednju vrijednost. Općenito, rezultati iz područja rješavanja problema bili su viši od rezultata u matematici osim za Nizozemsku. Uspoređujući Norvešku i Irsku, iako je Irska imala bolji rezultat u matematici, učenici iz Irske imali su prilično niska postignuća u rješavanju problema. Slično tome, iako su Srbija i Turska imale slična postignuća u matematici, Srbija je imala oko 20 bodova više od Turske u rješavanju problema.

Među tim vrijednostima treba spomenuti da su učenici iz Koreje imali više iskustva s matematičkim zadatcima te su imali puno izvannastavnih matematičkih aktivnosti. Iako su učenici iz Koreje dobili visoke rezultate u rješavanju problema, učenici su izjavili da nisu baš otvoreni prema rješavanju problema. Nadalje, razredi u Turskoj i Koreji više su popunjeni od ostalih zemalja. Zemlje s niskim postignućima, Srbija i Turska, imale su ograničene obrazovne resurse u školi u odnosu na druge zemlje.

Tablica 2 


\section{Čimbenici predviđanja postignuća u rješavanju problema}

Pretpostavke višerazinske regresijske statistike su provjerene. Provjerena je normalnost, linearnost i homogenost varijance greške kod pretpostavki. Proučavanje ostalih podataka daje informaciju o pretpostavkama normalnosti, linearnosti i heteroskedastičnosti (Hox, 2010). Za testiranje navedenih pretpostavki standardizirana rezidualna odstupanja testirana su nasuprot predviđenoj matrici vrijednosti (Tabachnick i Fidell, 2013). Uočeno je da kod svih zemalja te pretpostavke nisu narušene.

Za dobivanje odgovora na prvo pitanje i potvrđivanje hipoteze, rezultati višerazinske regresije prikazani su za svaku zemlju (vidi Tablicu 3). Ti rezultati ukazuju na mogućnost predviđanja postignuća učenika u rješavanju problema u zemljama s visokim, srednjim i niskim postignućima koristeći se čimbenicima učenika i čimbenicima škole. Varijable učenika objasnile su odstupanje kod postignuća u rješavanju problema različito za svaku zemlju, od 10\% (Srbija) do 22\% (Koreja i Irska) (medijan je 15,5\%). Razlika objašnjenih odstupanja unutar škola među zemljama podrazumijeva da je višerazinski model istraživanja učinkovitiji za Koreju, Irsku i Norvešku u usporedbi s ostalim zemljama. To znači da kod Nizozemske, Srbije i Turske postoje druge varijable učenika koje mogu objasniti razlike među učenicima, poput anksioznosti. Otvorenost prema rješavanju problema i iskustvo s čistim matematičkim zadatcima dvije su varijable koje su pozitivno predvidjele postignuće u rješavanju problema u svim zemljama. Stoga učenici koji su otvoreniji za rješavanje problema i koji imaju više iskustva s čistim matematičkim zadatcima imaju bolje rezultate u rješavanju problema. Iznenađuje da iskustvo s primijenjenim matematičkim zadatcima, osim u Koreji - zemlji s najvišim postignućima -,negativno predviđa postignuća u rješavanju problema. ESCS pozitivno predviđa postignuća u rješavanju problema u zemljama sa srednjim i niskim postignućima. To znači da učenik s boljim resursima kod kuće postiže bolje rezultate u rješavanju problema. Međutim, u Koreji i Nizozemskoj, zemljama s najvišim postignućima, nije uočena povezanost između ESCS i rješavanja problema. Stoga se zaključuje da kod zemalja s visokim postignućima ESCS nema ulogu prediktora. Među varijablama učenika upornost pozitivno predviđa postignuće u rješavanju problema samo u slučaju Norveške i Irske.

Varijable na razini škole objašnjavaju odstupanja u postignućima rješavanja problema varirajući od 3\% (u Norveškoj) do 39\% (u Nizozemskoj) (medijan je 24\%). Objašnjeno odstupanje škole u višerazinskom modelu gotovo je jednako učinkovito u predviđanju rješavanja problema osim u Norveškoj. Za Norvešku su objašnjena odstupanja bila vrlo niska te je zaključeno da druge varijable na razini škole mogu objasniti razlike među školama. Varijable škole ne pokazuju sustavni obrazac u predviđanju postignuća $\mathrm{u}$ rješavanju problema kao što to čine varijable učenika. Izvannastavne matematičke aktivnosti u školama imaju pozitivnu povezanost s postignućima u rješavanju problema u Koreji i u Turskoj. Škole s više nastavnika s ISCED 5A i više učenika u razredima pokazale su bolja postignuća u Nizozemskoj i Irskoj. Škole s većim brojem licenciranih nastavnika bile se učinkovitije u rješavanju problema u Srbiji. 
Kvaliteta školskih obrazovnih resursa značajan je prediktor rješavanja problema samo u Koreji i Turskoj, i to negativno i pozitivno. Samo izvannastavne kreativne aktivnosti nisu pokazale povezanost $s$ rješavanjem problema ni u jednoj zemlji. Prema tome, može se parcijalno zaključiti da manje učenika u razredu i obrazovani nastavnicima koji provode više matematičkih izvannastavnih aktivnosti mogu dovesti do boljih postignuća u rješavanju problema.

Tablica 3

\section{Usporedba očekivanih postignuća u rješavanju problema s obzirom na postignuća u matematici}

Odgovor na drugo istraživačko pitanje i potvrđivanje hipoteze nalaže istraživanje različitih očekivanih postignuća u rješavanju problema u navedenim zemljama s obzirom na slična matematička postignuća. Postignuća u rješavanju problema kontrolirajući i nekontrolirajući (modificirana srednja vrijednost) postignuća u matematici prikazana su u Tablici 4. Prije svega, bez kontroliranja postignuća u matematici, napravljena je jednosmjerna analiza ANOVA među predmetima kako bi se usporedile razlike u postignućima u rješavanju problema. Utvrđeno je da postoji statistički značajna razlika među tim zemljama $\left(F(5,28721)=756,78 ; p=, 000 ; \eta^{2}=\right.$ ,12). Zatim je kontroliranjem postignuća u matematici napravljena analiza ANCOVA kako bi se usporedile razlike u očekivanim postignućima u rješavanju problema. Ponovno je utvrđena značajna razlika među navedenim zemljama $(F(5,28720)=$ 198,$\left.04 ; p=, 000 ; \eta^{2}=, 01\right)$. ETA-kvadrat vrijednost prije kontroliranja postignuća u matematici ukazala je srednju razinu razlika među zemljama. Međutim, kod kontrole postignuća u matematici, ETA-kvadrat vrijednost ukazala je na malu razinu razlika među zemljama. (Cohen, 1988). ETA-kvadrat vrijednost dramatično je smanjena ukazujući na to da bi razlike u rezultatima bile manje u rješavanju problema da su te zemlje imale slične rezultate u matematici. Stoga je odgovor na drugu hipotezu da bi razlika u postignućima rješavanja problema manja među zemljama bila manja da su učenici imali slična postignuća u matematici.

Post-hoc analize, koristeći se Bonferronijevom procedurom, provedene su kako bi se vrednovale razlike među parovima kod modificiranih srednjih vrijednosti za rješavanje problema. Rezultati pokazuju da bi, iako modificirana, postignuća u rješavanju problema bila niža za Koreju, Koreja i dalje imala bolja postignuća od drugih zemalja, izuzev Srbije. Rezultati vezani uz Nizozemsku i Srbiju su interesantni i podložni daljnjoj analizi. Nizozemska bi dobila najniži rezultat, a Srbija bi bila među zemljama s najboljim postignućem u području rješavanja problema kada bi sve zemlje imale slična postignuća u matematici. Slično tome, Turska bi poboljšala postignuća u rješavanju problema kada bi imala slična postignuća u matematici kao i ostale zemlje. Norveška i Irska pokazale su slična postignuća s kontrolom ili bez kontrole postignuća u matematici.

Tablica 4 


\section{Otklanjanje mogućih učinaka razlika s obzirom na razred u PISA ispitivanjima}

PISA je za cilj imala izmjeriti koliko su dobro 15-godišnjaci obrazovani za suočavanje sa stvarnim životnim problemskim situacijama koje prije nisu doživjeli. S obzirom na to da se PISA usredotočuje na dob učenika kada se odlučuje na uzorak, razredi koji su podvrgnuti istraživanju su od 7. do 12. razreda. Kako bi se otklonili učinci razlika s obzirom na razred u ovome istraživanju, podatci za 9. i 10. razred su filtrirani, a zatim je provedena ponovna analiza. Novi podatci prikazani su u tablicama 5,6 i 7. Prikazane su srednje vrijednosti za varijable učenika i škole, standardizirani koeficijenti regresije koji su se koristili za predviđanje postignuća u rješavanju problema s kontrolom ili bez kontrole postignuća u matematici. Usporedbom tablica 3 i 6 jedina statistički značajna razlika utvrđena je za ESCS u predviđanju postignuća nizozemskih učenika u rješavanju problema nakon što su uklonjene varijacije prema razredu. Za ostale tablice nisu utvrđene razlike. Prema tome, može se reći da razina razreda ne donosi važnije nepoželjno odstupanje u rezultatima ovoga istraživanja.

Tablica 5, 6 i 7

\section{Rasprava i zaključak}

$\mathrm{U}$ ovome su se istraživanju varijable učenika i škole koje su bile učinkovite u predviđanju kompetencije rješavanja problema kod učenika identificirale korištenjem podataka iz šest zemalja s različitim postignućima u PISA 2012 ispitivanju rješavanja problema iz matematike. Nadalje, postignuća u rješavanju problema u tim zemljama uspoređena su kontrolom njihova postignuća u matematici. Očekuje se da će navedeni nalazi doprinijeti literaturi dajući zajedničke poticaje postignućima kreativnoga rješavanja problema, što je novo područje PISA 2012. PISA 2012 istraživanje kreativnoga rješavanja problema usredotočuje se na opće kognitivne procese kako bi učenici riješili probleme na koje bi mogli naići u svakodnevnome životu, za razliku od problema na koje mogu naići u određenom školskom predmetu. Situacijama utemeljenima na specifičnim i kurikulskim ciljevima PISA se nije koristila u području rješavanja problema (OECD 2014a). Poboljšanje kompetencije rješavanja problema važno je s obzirom na to da postoji vjerojatnost da će učenici koji su bolji u rješavanju problema imati bolja postignuća i u drugim predmetima (OECD 2014a).

Rezultati utemeljeni na varijablama učenika pokazuju da Walbergove varijable učeničkih sposobnosti, otvorenost za rješavanje problema i upornost; Walbergove varijable poučavanja, iskustvo s čistim matematičkim zadatcima; Walbergove varijable okoliša, ESCS, općenito pozitivno predviđaju postignuće u rješavanju problema. Međutim, Walbergova varijabla poučavanja, iskustvo s primijenjenim matematičkim zadatcima, negativno predviđa postignuća u rješavanju problema u svim zemljama izuzev Koreje. Rezultati utemeljeni na varijablama škole ukazuju na to da Walbergova varijabla okoliša, udio nastavnika s ISCED 5A, udio licenciranih nastavnika i veličina 
razreda; zatim Walbergova varijabla poučavanja - matematičkih izvannastavnih aktivnosti pozitivno predviđa postignuće $u$ rješavanju problema u nekim zemljama. Kvaliteta školskih obrazovnih resursa mješovito je povezana s postignućima u rješavanju problema. Konačna analiza, ANCOVA, pokazala je da se razlike u rješavanju problema među zemljama smanjuju kada je kontrolirano postignuće u matematici. Detaljna rasprava o varijablama učenika i škole kao prediktora rješavanja problema prema Walbergovu modelu kao i povezanost rješavanja problema s postignućima $u$ matematici prikazani su u daljnjem dijelu rada.

\section{Varijable učenika}

\section{Walbergove varijable sposobnosti učenika}

Otvorenost za rješavanje problema i upornost motivacijski su i afektivni čimbenici utemeljeni na volji i zadovoljstvu učenika da se uključi u rješavanje problema unatoč mogućim preprekama. U ovome istraživanju, za sve zemlje, neovisno o tome imaju li visoka ili niska postignuća, uočena je pozitivna povezanost između postignuća $u$ rješavanju problema i otvorenosti za rješavanje problema. Ta pozitivna povezanost ukazuje na to da visok rezultat u rješavanju problema može biti u funkciji otvorenosti za aktivnosti rješavanja problema. Učenici koji tvrde da su brzi u razumijevanju problema i koji vole rješavati složene probleme imali su bolja postignuća. Slično tome, razina upornosti učenika pozitivno predviđa postignuća rješavanja problema, ali samo u zemljama sa srednjim postignućima (Norveška i Irska). Učenici koji nisu lako odustali od rješavanja složenih zadataka bili su uspješniji u rješavanju problema. Ti pronalasci usklađeni su s postojećim istraživanjima o otvorenosti za rješavanje problema i upornosti na postignuća učenika (Funke, 2010; Kogar, 2015; Mayer, 1998; Perkins i Shiel, 2014; Scherer i Gustafsson, 2015). Ulaganje u ta dva promjenjiva čimbenika mogao bi biti ključ za bolja postignuća u rješavanju problema s obzirom na to da definicija rješavanja problema sadrži i motivacijsku komponentu (OECD, 2013a). Stoga se može očekivati da bi aktivnosti koje učvršćuju pozitivne stavove učenika prema rješavanju problema mogle poboljšati rezultate u rješavanju problema (Van de Walle, Karp, i Williams, 2007). Nadalje, poučavanje neuobičajenih strategija rješavanja problema i načina za suočavanje sa složenim zadatcima moglo bi poboljšati otvorenost učenika za rješavanje problema i njihovu razinu upornosti.

\section{Walbergove varijable poučavanja}

Iskustva s čistim matematičkim zadatcima i zadatcima iz primijenjene matematike indikatori su prilike za učenje. Prilika za učenje (OTL) definirana je kao učenikovo prijašnje izlaganje sadržaju predmeta u školi (Schmidt i Maier, 2009). Svi dionici obrazovnoga sustava odgovorni su za davanje jednakih prilika učenicima (Stevens i Grymes, 1993). OTL je važan prediktor uspjeha, odnosno postignuća (Meyers i Rogers, 2014; Schmidt i Maier, 2009; Schmidt, Zoido, i Cogan, 2014). Istraživanje je dalo mješovite rezultate učeničkoj percepciji iskustava s čistim i primijenjenim 
matematičkim zadatcima. Dok iskustva s čistim matematičkim zadatcima pozitivno predviđaju rezultate rješavanja problema u svim zemljama, iskustvo s primijenjenim matematičkim zadatcima negativno predviđa postignuća u rješavanju problema $u$ gotovo svim zemljama (izuzev Koreje). Standardizirani regresijski koeficijenti za iskustvo s čistim matematičkim zadatcima bili su viši od iskustva s primijenjenim matematičkim zadatcima, što može ukazati na moguću pozitivnu povezanost iskustva $\mathrm{s}$ matematičkim zadatcima i postignućima u rješavanju problema. Ti su rezultati utemeljeni na odstupanjima unutar zemalja. Nadalje, na osnovi deskriptivnih analiza, $s$ obzirom na razlike među zemljama, uočeno je da zemlje s visokim postignućima imaju viši rezultat srednje vrijednosti kod iskustva s čistim i primijenjenim matematičkim zadatcima, a da zemlje s nižim postignućima imaju manji rezultat srednje vrijednosti za čiste i primijenjene matematičke zadatke koji mogu upućivati na pozitivan odnos.

Negativan odnos između iskustva s primijenjenim matematičkim zadatcima i rezultatima rješavanja problema bio je neočekivan s obzirom na to da PISA tvrdi da mjeri kompetenciju rješavanja problema u scenarijima svakodnevnoga života s minimalnim matematičkim sadržajem. Stavke koje mjere iskustva s primijenjenim matematičkim zadatcima tražile su iz perspektive učenika učestalost iskustava sa zadatcima poput „iz priloženog reda vožnje vlakova izračunaj koliko bi ti trebalo da dođeš od jednoga mjesta do drugoga”. Učenici su trebali utvrditi učestalost, međutim kvaliteta poučavanja utemeljena na tim zadatcima nije mjerena. Podatci također nisu dali informacije o načinu na koji su nastavnici prezentirali čiste i primijenjene matematičke zadatke učenicima. Neki nastavnici prikazivali su samo primijenjene matematičke zadatke kako bi povećali pažnju učenika s nižim postignućima, ali ne i učenicima s visokim postignućima (OECD, 2013c). Nastavnici se mogu više usredotočiti na uobičajene probleme kod primijenjenih aktivnosti koje ograničavaju razvoj kompetencije kreativnoga rješavanja problema. Potrebna su detaljnija istraživanja kako bi se ti odnosi istražili.

\section{Walbergova varijabla okoliša}

Prijašnja istraživanja uglavnom su ukazivala na pozitivan odnos ESCE i rješavanja problema ili postignuća u matematici (Akyüz i Pala, 2010; Alacacı i Erbaş, 2010; Bae i Wickrama, 2015; Perkins i Shiel, 2014). U PISA 2012 procjeni matematike učenici višeg društveno-ekonomskog statusa u prosjeku su postigli 78 bodova više od učenika u nepovoljnijem položaju (OECD, 2013d). Ovo istraživanje utvrdilo je slične rezultate u odnosu ESCS i postignuća u rješavanju problema. Za zemlje sa srednjim i nižim postignućima uočena je pozitivna povezanost, međutim kod zemalja $s$ visokim postignućima uočena je pozitivna, ali ne i značajna povezanost. $S$ obzirom na to da je u PISA, ESCS indikator profesionalnoga, obrazovnoga, financijskoga, kulturnoga, kućnih obrazovnih resursa i razine obrazovanja roditelja, nije ga baš jednostavno mijenjati. Ono što se može napraviti jest dati jednake prilike učenicima svih društveno-ekonomskih statusa. Iako ta pozitivna povezanost ne dovodi do 
uzročno-posljedične veze, društveno-ekonomske razlike, posebno kod zemalja sa srednjim i niskim postignućima mogle bi dovesti do diferencijacije kod postizanja visoko-kvalitetnih nastavnika i škola. Uspješni školski sustavi su oni koji mogu ravnopravno raspodijeliti resurse (OECD, 2013b).

\section{Varijable škole}

\section{Walbergove varijable poučavanja}

Pokazalo se da matematičke izvannastavne aktivnosti imaju pozitivnu povezanost $s$ rješavanjem problema kod zemalja s najvišim postignućima i kod zemalja s najnižim postignućima (Koreja i Turska). Za ostale zemlje regresijski koeficijenti bili su pozitivni, ali ne i značajni. Taj rezultat ukazuje na to da učenici u školama koje nude matematički klub, matematička natjecanja, klubove računarstva i IKT, zatim koje nude dodatne sate iz matematike imaju općenito bolje rezultate $\mathrm{u}$ rješavanju problema. $U$ istraživanju nije uočena povezanost između rezultata u rješavanju problema i izvannastavnih kreativnih aktivnosti u školi poput benda, orkestra, zbora, školske predstave, školskog mjuzikla, umjetničkog kluba. Istraživanja o povezanosti matematičkih izvannastavnih aktivnosti ili izvannastavnih kreativnih aktivnosti i postignuća u PISA vrednovanju su rijetka. Bove, Marella i Vitale (2016) izvijestili su o pozitivnoj povezanosti između matematičkih izvannastavnih aktivnosti i postignuća u matematici, ali nisu uočili povezanost između izvannastavnih kreativnih aktivnosti i postignuća u matematici. S obzirom na to da su rezultati matematičkih izvannastavnih aktivnosti i izvannastavnih kreativnih aktivnosti dobiveni iz izvješća ravnatelja o školskim aktivnostima, nismo mogli znati kako su se te aktivnosti provodile. Ulaganje u matematičke klubove, posebno u školama s niskim postignućima, moglo bi dovesti do boljih postignuća učenika. Međutim, vrlo je važno znati kako ti klubovi funkcioniraju. Izvođenje pomno planiranih aktivnosti rješavanja problema u tim programima moglo bi dovesti do povećanja učinkovitosti samih programa, što bi dovelo do boljih učeničkih ishoda. $S$ obzirom na to da PISA također mjeri kreativnost u vrednovanju rješavanja problema, izvannastavne aktivnosti koje potiču netipične vještine rješavanja problema bile bi korisne. Te aktivnosti trebale bi se planirati s obzirom na kognitivnu razinu učenika kako bi promovirale razumijevanje na konceptualnoj razini.

\section{Walbergove varijable okoliša}

U Nizozemskoj i Irskoj udio nastavnika s ISCED 5A, što je rang jednak sveučilišnoj diplomi, i u Srbiji, udio licenciranih nastavnika pozitivan je prediktor postignuća u rješavanju problema. Te dvije varijable indikatori su bolje obrazovanih nastavnika. Ma i Ma (2014) izvijestili su o mješovitim rezultatima za povezanost kvalitete nastavnika i postignuća u PISA vrednovanju. Deskriptivna statistika pokazala je da zemlje koje nisu imale značajnu povezanost, imaju srednju vrijednost blizu 1. Ta vrijednost ukazuju na to da u tim zemljama gotovo svi nastavnici imaju razine obrazovanja ili certifikate, što ograničava odstupanja. Kada bi bilo više odstupanja s obzirom na razinu, bili bi 
utvrđeni značajni odnos. Neovisno o tome, očekuje se da ulaganje u obrazovanje učitelja i u stručno usavršavanje učitelja može dovesti do poboljšanja postignuća u rješavanju problema.

Veličina razreda i kvaliteta obrazovnih resursa u školi povezani su s postignućima u rješavanju problema na nekoliko načina. Samo u Nizozemskoj i Irskoj postoji pozitivna povezanost između veličine razreda i rezultata u rješavanju problema. $S$ obzirom na to da obje zemlje imaju najniže srednje vrijednosti za veličinu razreda ( 25,18 i 24,90 , pojedinačno), taj rezultat nalaže opreznu analizu. Što se tiče ostalih zemalja, povezanost nije bila uočena. $U$ mnogim istraživanjima značajna povezanost između veličine razreda i postignuća nije uočena (Cordero, Crespo, i Santin, 2010; Fuchs i Wößmann 2007; Sousa, Park, i Armor, 2012). Obrazovni resursi škole pozitivni su prediktori učeničkih postignuća u Turskoj, a negativni u Koreji. Indeks kvalitete školskih obrazovnih resursa odnosi se na opremu za znanstvene laboratorije, materijale za poučavanje, računala, internetsku vezu, računalni softver sa svrhom poučavanja i knjižnične građe u školi. Zemlje s niskim postignućima poput Turske imaju višu neujednačenost $u$ raspodjeli obrazovnih resursa. Bolje škole imaju više resursa. Učenici u nepovoljnijem položaju imaju problema s upisima u bolje škole, što stvara jaz u postignuću. Jednakomjerna raspodjela resursa školama u povoljnom i nepovoljnom položaju mogla bi dovesti do boljih postignuća.

\section{Povezanost rješavanja problema i postignuća u matematici}

PISA izvješćuje i u svojoj analizi valjanosti da je područje rješavanja problema različito od područja matematike i ostalih područja. Različiti rezultati među učenicima i školama u postignuću rješavanja problema ne dolaze isključivo iz razlika u postignuću iz matematike (OECD, 2014a). Poredak zemalja kod rješavanja problema i matematike nije bio isti. Koreja, Norveška i Srbija imaju bolja očekivana postignuća, a Nizozemska, Irska i Turska imaju niža postignuća od očekivanih u rješavanju problema u odnosu na njihova postignuća u matematici. Međutim, u određenoj mjeri postoje važne povezanosti između postignuća u rješavanju problema i postignuća u matematici. Ovo istraživanje pokazalo je da bi, ako bi svi učenici imali slična postignuća u matematici, razlika u postignućima u rješavanju problema među zemljama bila manja. Stoga bi se povećanjem postignuća učenika u matematici, poglavito u zemljama s niskim postignućima, moglo neizravno povećati i postignuće u rješavanju problema.

Novina u ovome istraživanju jest ispitivanje prediktora kompetencije kreativnoga rješavanja problema. S obzirom na to da se ta kompetencija počela sveobuhvatno prvi put mjeriti u PISA 2012, istraživanja koja možemo povezati su ograničena. PISA nudi podatke kojima se mogu usporediti rezultati zemalja. Ovo istraživanje uočilo je zajedničke i specifične prediktore rješavanja problema u različitim zemljama. Iako svaka zemlja ima svoje karakteristike, zajednički čimbenici ukazuju na važne indikatore kojima možemo poboljšati kompetenciju rješavanja problema koja je važna za uspješan život u modernom društvu. Činjenica da PISA nastavlja s provođenjem 
zasebnih vrednovanja kreativnoga rješavanja problema, očekuje se i više istraživanja, uključujući i longitudinalna.

\section{Implikacije}

Ovo istraživanje ima nekoliko implikacija. Rezultati istraživanja utemeljeni su na povezanosti među varijablama koje ne podrazumijevaju uzročnost. Međutim, promjene u tim varijablama prediktora mogu uzrokovati promjenu kod sposobnosti rješavanja problema. Stoga uz takav probabilistički pristup dajemo i ove implikacije.

1. Aktivnosti koje bi mogle potaknuti pozitivan stav učenika prema rješavanju problema ili koje bi ih potaknule na bavljenje problemima bile bi korisna. Te aktivnosti mogle bi biti sastavni dio poučavanja ili bi se mogle ponuditi kao semestralni projekti.

2. Postoji prilika za smanjenjem jaza između i unutar zemalja. Povećanjem iskustava s matematičkim zadatcima, posebno kod onih koji imaju ograničene prilike, poboljšale bi se vještine rješavanja problema. Mogao bi se povećati broj izvannastavnih matematičkih aktivnosti koje potiču različito, neuobičajeno rješavanje problema.

3. S obzirom na povezanost matematike i rješavanja problema, poboljšanjem postignuća u matematici očekuje se poboljšanje i u postignuću rješavanja problema. Stoga treba nastaviti sa stavljanjem naglaska nastavnika na matematiku. 